\title{
Non-Precious Electrocatalysts for Oxygen Reduction Reaction in Alkaline Media: Latest Achievements on Novel Carbon Materials
}

\author{
Angeliki Brouzgou ${ }^{1}$, Shuqin Song ${ }^{2, *}$, Zhen-Xing Liang ${ }^{3, *}$ and Panagiotis Tsiakaras ${ }^{1,4, *}$ \\ 1 Laboratory of Alternative Energy Conversion Systems, Department of Mechanical Engineering, \\ University of Thessaly, Pedion Areos, Volos 38334, Greece; brouzgou@gmail.com \\ 2 Key Laboratory of Low-Carbon Chemistry and Energy Conservation of Guangdong Province, \\ School of Materials Science and Engineering, Sun Yat-sen University, Guangzhou 510275, China \\ 3 Key Laboratory on Fuel Cell Technology of Guangdong Province, \\ School of Chemistry and Chemical Engineering, South China, University of Technology, \\ Guangzhou 510641, China \\ 4 Laboratory of Electrochemical Devices Based on Solid Oxide Proton Electrolytes, \\ Institute of High Temperature Electrochemistry, Russian Academy of Sciences, \\ Yekaterinburg 620137, Russia \\ * Correspondence: stsssq@mail.sysu.edu.cn (S.S.); zliang@scut.edu.cn (Z.-X.L.); tsiak@uth.gr (P.T.); \\ Tel.: +86-20-8411-3253 (S.S.); +86-20-8711-3584 (Z.-X.L.); +30-24210-74065 (P.T.)
}

Academic Editors: Vincenzo Baglio and David Sebastián

Received: 1 August 2016; Accepted: 26 September 2016; Published: 19 October 2016

\begin{abstract}
Low temperature fuel cells (LTFCs) are considered as clean energy conversion systems and expected to help address our society energy and environmental problems. Up-to-date, oxygen reduction reaction (ORR) is one of the main hindering factors for the commercialization of LTFCs, because of its slow kinetics and high overpotential, causing major voltage loss and short-term stability. To provide enhanced activity and minimize loss, precious metal catalysts (containing expensive and scarcely available platinum) are used in abundance as cathode materials. Moreover, research is devoted to reduce the cost associated with Pt based cathode catalysts, by identifying and developing Pt-free alternatives. However, so far none of them has provided acceptable performance and durability with respect to Pt electrocatalysts. By adopting new preparation strategies and by enhancing and exploiting synergetic and multifunctional effects, some elements such as transition metals supported on highly porous carbons have exhibited reasonable electrocatalytic activity. This review mainly focuses on the very recent progress of novel carbon based materials for ORR, including: (i) development of three-dimensional structures; (ii) synthesis of novel hybrid (metal oxide-nitrogen-carbon) electrocatalysts; (iii) use of alternative raw precursors characterized from three-dimensional structure; and (iv) the co-doping methods adoption for novel metal-nitrogen-doped-carbon electrocatalysts. Among the examined materials, reduced graphene oxide-based hybrid electrocatalysts exhibit both excellent activity and long term stability.
\end{abstract}

Keywords: oxygen reduction reaction; low temperature fuel cells; non-precious carbon-based electrocatalysts; hybrid electrocatalysts; macro-mesoporous structure; co-doping

\section{Introduction}

The design and the development of highly efficient, stable and low cost oxygen reduction reaction (ORR) electrocatalysts is one of the main determining steps for the fabrication of more commercially viable electrochemical devices (fuel cells, electrolyzers, metal-air batteries, etc.). 
During the last two decades, a joint effort has been made by the international research community towards: (i) the development of low-loading precious metal electrocatalysts; (ii) the development of non-Pt electrocatalysts; (iii) the development of new supporting materials; and (iv) the investigation of novel preparation methods [1].

Among the various developed non-Pt electrocatalysts, Ir- and Pd-based ones have attracted much more attention, as they exhibited comparable activity with Pt-based electrocatalysts, though in the presence of methanol or ethanol due to alcohol crossover, they exhibited much lower stability and less activity than Pt-based ones [1]. Moreover, different supports such as tungsten carbides, carbon nanotubes, and nitrogen-modified carbon were investigated and adopted, but without the expected results [2].

During the last decade, along with the development of alkaline membranes, their promising performance, in major cases better than that of the acidic membranes, significantly boosted further investigation on the non-Pt electrocatalysts [3]. Among the non-Pt electrocatalysts, heteroatom-doped carbon materials are currently considered as the most potential $\mathrm{Pt}$ substitutes for the oxygen reduction reaction (ORR) [4]. Various heteroatoms, such as N [5-8], B [7,8], S [9-11], Fe [12,13], and P [7,14-16], with different electronegativity, have been doped for nanotubes [17], graphene [18], graphite [19], etc.

The doped-carbons show excellent ability to adsorb and bond $\mathrm{OOH}^{\bullet}$, significantly enhancing the formation of $\mathrm{H}_{2} \mathrm{O}_{2}$. This facile ORR activity has been attributed to the fact that carbon atoms next to heteroatoms are the catalytically active sites and to the modification of carbon electronegativity. For instance, in $\mathrm{N}$-doped carbon, a charge separation occurs due to the different electronegativity values, in which the positive pole is favorable for oxygen adsorption, enhancing the ORR. In terms of alcohol crossover, the carbon-based catalyst shows an extremely high selectivity to the ORR and inactivity to alcohol oxidation reaction. The reason mostly lies in the high activation energy for the chemical dissociative adsorption of the hydrocarbon compounds on such catalysts.

Furthermore, it has been observed that co-doping with two heteroatoms creates a higher number of catalytically active sites than single-doped counterparts. Thus, many of the ORR investigations in the last two years were devoted to $\mathrm{N}$-doped carbon catalysts with another element [8]. For example, Fe-N doped carbon systems have shown excellent ORR performance in both alkaline and acid electrolytes, due to the metal-nitrogen synergetic effect [13]. The significant contribution of nitrogen when being doped in carbon has been reported since 2009. Niwa et al. [20] investigated different electronic structures of nitrogen (pyridinic, graphitic, pyrrolic, oxidic, proposing that graphitic-like nitrogen is the main reason for the enhanced ORR activity of N-doped carbon electrocatalysts.

The mesoscopic morphology, the high surface area, the pore size and the order degree reflect the available active sites of a carbon material, and consequently affect its electrocatalytic activity. Most of the synthesis strategies of doped carbon material with high surface area include multi-step chemical processes, with some of them to be of high cost. Consequently, sometimes due to the complexity of the synthesis procedure of hetero-atom doped carbon materials it is difficult to designate the nature of catalytically active sites for ORR, which is of high importance for understanding the whole ORR process [21].

The key issue to obtain optimal ORR activities by using doped-carbons lies in: (i) uniform doping of heteroatoms (ii) unique nanostructure with high surface area; and (iii) suitable mesopore distribution. In most of the preparation methods, carbon support is either post-treated with heteroatom substances $[7,8,15]$, or obtained through direct co-pyrolysis of the heteroatom-containing organic compounds with carbon under inert gas atmosphere [22,23].

However, a sufficiently doped and finely controlled structure is rather difficult to be simultaneously achieved. Therefore, a uniform distribution of dopants into a well-designed carbon matrix with significantly enhanced ORR performance still remains a challenging goal. A second target to be achieved concerns the choice of the appropriate precursor in combination with the pyrolysis conditions, to obtain large surface area, high nitrogen content and, thus, high performance to be attained. 
The deliberated defects on carbon structures lead to the destruction of its conductivity, which is the most essential characteristic in electrocatalytic processes [4]. For this reason, in the last years, researchers have turned their attention to carbons with graphitic structure, such as graphene; the conductivity of which is not influenced by introducing heteroatoms.

The current review focuses on different strategies very recently developed by different research groups in order to enhance the activity of non-precious metal, namely carbon based electrocatalysts towards ORR. Mainly, four strategies have been distinguished: (i) the fabrication of 3D structure including interconnected networks by modifying carbon structure; (ii) the development of novel hybrid materials; (iii) the adoption of alternative precursor for a more homogeneous distribution of the heteroatoms into carbon matrix; and (iv) the co-doping technique of two heteroatoms, mainly into highly ordered mesoporous materials.

\section{2D and 3D Doped-Carbon Electrocatalysts}

Two-dimensional (2D) and three-dimensional (3D) porous structures with controllable compositions can provide high activity and stability for ORR due to their interconnected open-pore structure, which can facilitate electron and mass transfer. In addition, the offered large active area of mesopore structure that can provide more active sites, in combination with microporous structure that reduces the electrolyte diffusion distances to the interior surfaces and serves as an electrolyte buffering reservoir, significantly enhances the ORR activity $[24,25]$. The addition of nitrogen at this advantageous carbon structure further facilitates ORR.

Recently, it has been reported that hierarchically porous materials offer greater active surface area via their interconnected macro-porosity [26]. Liu et al. [27], for the N-doped hierarchically porous carbon pyrolysed at $1000{ }^{\circ} \mathrm{C}$, reported a kinetic-limiting current density $\left(J_{\mathrm{k}}\right)$ of $20.0 \mathrm{~mA} \cdot \mathrm{cm}^{-2}$ at $0.853 \mathrm{~V}$ (vs. RHE), a half wave-potential $\left(E_{1 / 2}\right)$ of $0.773 \mathrm{~V}$ (vs. RHE), an excellent methanol tolerance $(0.5 \mathrm{M})$ and $8.1 \%$ of current loss after 3.5 operational hours at $-0.5 \mathrm{~V} \mathrm{vs} \mathrm{Ag} / \mathrm{AgCl}$. The observed high ORR activity was attributed to the existence of 3D-hierarchically interconnected porous frameworks with high surface area, large pore volume and high conductivity.

$\mathrm{N}$-doped hierarchically macro/mesoporous carbon pyrolysed at the optimal temperature $\left(850^{\circ} \mathrm{C}\right)$ was also examined by Tao et al. [28]. By the aid of rotating disk electrode (RDE) measurements, they recorded a limiting current density close to $4.4 \mathrm{~mA} \cdot \mathrm{cm}^{-2}$ (1600 rpm), and a half-wave potential of $0.753 \mathrm{~V}$ (vs. RHE); in the presence of $3.0 \mathrm{M}$ methanol in $0.1 \mathrm{M} \mathrm{KOH}$ the activity was almost unchanged. Chronoamperometric test at $-0.55 \mathrm{~V}$ vs. $\mathrm{Ag} / \mathrm{AgCl}$ reveals that after $12.5 \mathrm{~h}$ durability test, the electrocatalyst lost only $5 \%$ of its activity, while a dramatic degradation of $15 \%$ was observed for $\mathrm{Pt} / \mathrm{C}$ after $2.5 \mathrm{~h}$.

The 3D dual-doped highly ordered macro-mesoporous structure is observed to provide more active ORR electrocatalysts than the single-doped one. Namely, 3D Co and N-doped highly ordered macro-mesoporous carbon electrocatalyst with the optimum content of cobalt displayed high activity towards ORR due to the presence of a large number of active sites. According to linear sweep voltammetry curves (LSV), a limiting current density of $5.8 \mathrm{~mA} \cdot \mathrm{cm}^{-2}$ in oxygen saturated alkaline environment and a half-wave potential $\left(E_{1 / 2}\right)$ of $0.83 \mathrm{~V}$ (vs. RHE), was observed [29]. The kinetic current density at $0.70 \mathrm{~V}$ vs. RHE was calculated close to $23.2 \mathrm{~mA} \cdot \mathrm{cm}^{-2}$, while in the presence of $1.0 \mathrm{M}$ of methanol, its ORR activity remained satisfactorily stable, indicating its high tolerance to the methanol. Additionally, after $25 \mathrm{~h}$ of continuous operation at $0.5 \mathrm{~V}$ vs. RHE, there was negligible current loss, in comparison with $\mathrm{Pt}(20 \mathrm{wt} \%) / \mathrm{C}$ that lost $~ 50 \%$ of its initial activity when examined under the same experimental conditions. [29].

Transition metal oxides, especially the doped-ones, have shown very good ORR activity [30]. The role of $\mathrm{Ni}$-doping in $\mathrm{MnO}_{2}$ nanoneedles for the ORR in alkaline media was recently investigated by Hao et al. [31]. The increment of Mn(III), which serves as electrochemical active site, according to the authors, is the main reason for its higher activity, in comparison to the other samples. The ORR activity is enhanced when transition metals are adopted in 3D hierarchical porous spinel hollow 
nanospheres, especially those with spinel structure [32,33]. Hollow structure also contributes to the increment of the number of active sites. More precisely, $\mathrm{CoFeO}_{2} 3 \mathrm{D}$ hollow nanospheres benefited the formation of a large three-phase boundary (solid-liquid-gas), which is necessary for the transfer of reactants and products. The yielded limiting current density $\left(5.3 \mathrm{~mA} \cdot \mathrm{cm}^{-2}\right)$ decreased by $34 \%$ after 12-h durability test; whereas the $\mathrm{Pt} / \mathrm{C}$ electrocatalyst decreased by $54 \%$ under the same experimental conditions [34]. The enhanced stability was attributed to the combination of its hollow morphology with the hierarchically porous structure. However, according to LSV curves, its half-wave potential was $0.58 \mathrm{~V}$ vs. RHE, negatively shifted by $\sim 0.30 \mathrm{~V}$ compared with Pt. In general, even without a special 3D structure, transition metal spinel oxide nanoparticles (NPs) have shown really good ORR performance [35-37]. 3D hollow-structured $\mathrm{NiCO}_{2} \mathrm{O}_{4} / \mathrm{C} \mathrm{NPs}$ with interconnected pores as bifunctional electrocatalysts, which are transformed from solid $\mathrm{NiCo}_{2}$ alloy NPs, have also been investigated for ORR [35]. From the RDE measurements, a limiting current density of $5.7 \mathrm{~mA} \cdot \mathrm{cm}^{-2}$ and a half-wave potential of $0.68 \mathrm{~V}$ vs. RHE were recorded (Table 1 ). In addition, $\mathrm{NiCo}_{2} \mathrm{O}_{4} / \mathrm{C}$ showed a superior long-term stability over $\mathrm{Pt} / \mathrm{C}$ electrocatalyst. At a constant potential of $0.6 \mathrm{~V}$ vs. RHE, a current decay of only $9 \%$ after $10 \mathrm{~h}$ occurred, whereas a gradual decrease of $52 \%$ was recorded for $\mathrm{Pt} / \mathrm{C}$ under the same conditions.

Table 1. Non-precious 2D and 3D-structured doped-carbon ORR (oxygen reduction reaction) electrocatalysts.

\begin{tabular}{|c|c|c|c|}
\hline Catalyst & Preparation Method and Experimental Conditions & $\begin{array}{l}\text { Limiting Current }\left(J_{\mathrm{d}} ; \mathrm{d}=\mathrm{disc}\right) \\
\text { Kinetic Current Density }\left(J_{\mathrm{k}}\right) \\
\left.\text { Half Wave Potential }\left(E_{1 / 2}\right)\right)\end{array}$ & Reference \\
\hline $\begin{array}{l}\text { N-HCS (hierarchically } \\
\text { mesoporous spheres)-900 }\end{array}$ & $\begin{array}{l}\text { Nanocasting method, } 0.1 \mathrm{M} \mathrm{KOH} \text {, oxygen saturated } \\
20 \mathrm{mV} \cdot \mathrm{s}^{-1}, 1600 \mathrm{rpm}\end{array}$ & $\begin{array}{l}J_{\mathrm{d}}=4.7 \mathrm{~mA} \cdot \mathrm{cm}^{-2} \\
J_{\mathrm{k}}=20.0 \mathrm{~mA} \cdot \mathrm{cm}^{-2} @ 0.3 \mathrm{~V} \text { vs. } \\
\mathrm{Ag} / \mathrm{AgCl} \mathrm{sat.} \mathrm{KCl}(0.85 \mathrm{~V} \text { vs. RHE }) \\
E_{1 / 2}=0.748 \mathrm{~V} \text { vs. RHE }\end{array}$ & [27] \\
\hline $\begin{array}{l}\text { 3D-HPC-N } \\
\text { (N-doped-3D-hierarchically } \\
\text { porous carbon materials)-850 }\end{array}$ & $\begin{array}{l}\text { Hierarchically macro/mesoporous silica as a hard } \\
\text { template followed by a simple N-doping procedure } \\
\text { and } 0.1 \mathrm{M} \mathrm{KOH} \text {, oxygen saturated } \\
5 \mathrm{mV} \cdot \mathrm{s}^{-1}, 1600 \mathrm{rpm}(0.1 \mathrm{M} \mathrm{KOH}+3.0 \mathrm{M} \mathrm{MeOH})\end{array}$ & $\begin{array}{l}J_{\mathrm{d}}=4.4 \mathrm{~mA} \cdot \mathrm{cm}^{-2} \\
\text { (Inactive in MeOH presence) } \\
E_{1 / 2}=0.753 \mathrm{~V} \text { vs. RHE }\end{array}$ & [28] \\
\hline $\begin{array}{l}3 \mathrm{D} \mathrm{Co}-\mathrm{N}-\mathrm{OMMC}-0.6 \\
\left(\mathrm{Co}\left(\mathrm{NO}_{3}\right)_{2} \cdot 6 \mathrm{H}_{2} \mathrm{O}\right) \text { (ordered } \\
\text { macro-mesoporous carbon) }\end{array}$ & $\begin{array}{l}\text { Dual-templating synthesis approach in a one-pot } \\
\text { controllable procedure by the use of silica colloidal } \\
\text { crystal (opal) as a macroporous mold and triblock } \\
\text { copolymer Pluronic F127 as a mesoporous template } \\
\text { and } 0.1 \mathrm{M} \mathrm{KOH} \text {, oxygen saturated; } 5 \mathrm{mV} \cdot \mathrm{s}^{-1} \\
1600 \mathrm{rpm}(0.1 \mathrm{M} \mathrm{KOH}+1.0 \mathrm{M} \mathrm{MeOH})\end{array}$ & $\begin{array}{l}J_{\mathrm{d}}=5.8 \mathrm{~mA} \cdot \mathrm{cm}^{-2} \\
\text { (Inactive in MeOH presence), } \\
J_{\mathrm{k}}=23.2 \mathrm{~mA} \cdot \mathrm{cm}^{-2} @ 0.7 \mathrm{~V} \text { vs. RHE, } \\
E_{1 / 2}=0.83 \mathrm{~V} \text { vs. RHE }\end{array}$ & [29] \\
\hline $\begin{array}{l}3 \mathrm{D} \text { hierarchical } \\
\text { porous- } \mathrm{CoFe}_{2} \mathrm{O}_{4} \text { hollow } \\
\text { nanospheres }\end{array}$ & $\begin{array}{l}\text { Hydrothermal method and } 0.1 \mathrm{M} \mathrm{KOH} \text {, } \\
\text { oxygen saturated, } 10 \mathrm{mV} \cdot \mathrm{s}^{-1}, 1600 \mathrm{rpm}\end{array}$ & $\begin{array}{l}J_{\mathrm{d}}=5.3 \mathrm{~mA} \cdot \mathrm{cm}^{-2} \\
E_{1 / 2}=0.58 \mathrm{~V} \mathrm{vs} . \mathrm{RHE}\end{array}$ & [34] \\
\hline $3 \mathrm{D}$ hollow $\mathrm{NiCo}_{2} \mathrm{O}_{4} / \mathrm{C}$ & $\begin{array}{l}\text { Transformation from solid } \mathrm{NiCO}_{2} \text { alloy nanoparticles } \\
\text { through the Kirkendall effect and } 0.1 \mathrm{M} \mathrm{KOH} \text {, } \\
\text { oxygen saturated, } 5 \mathrm{mV} \cdot \mathrm{s}^{-1}, 1600 \mathrm{rpm}\end{array}$ & $\begin{array}{l}J_{\mathrm{d}}=5.7 \mathrm{~mA} \cdot \mathrm{cm}^{-2} \\
E_{1 / 2}=0.68 \mathrm{~V} \text { vs. RHE }\end{array}$ & [35] \\
\hline $\begin{array}{l}\text { 3D Nanosheet } \\
\mathrm{Co}_{3} \mathrm{O}_{4} \text {-doped-graphene }\end{array}$ & $\begin{array}{l}\text { Microwave argon-plasma synthesis approach and } \\
0.1 \mathrm{M} \mathrm{KOH} \text {, oxygen saturated, } 5 \mathrm{mV} \cdot \mathrm{s}^{-1}, 1600 \mathrm{rpm}\end{array}$ & $\begin{array}{l}J_{\mathrm{d}}=5.7 \mathrm{~mA} \cdot \mathrm{cm}^{-2} \\
J_{\mathrm{k}}=34 \mathrm{mAcm}^{-2} @ 0.75 \mathrm{~V} \text { vs. RHE } \\
E_{1 / 2}=0.832 \mathrm{~V} \text { vs. RHE }\end{array}$ & [38] \\
\hline $\begin{array}{l}\text { 2D-CoAl-LDH@ZIF-67-800 } \\
\text { (LDH: layered double } \\
\text { hydroxides, ZIF: zeolitic } \\
\text { imidazolate framework) }\end{array}$ & $\begin{array}{l}\text { In situ nucleation and directed growth of MOFs } \\
\text { arrays on the surface of LDHs nanoplatelets } \\
\text { followed by a subsequent pyrolysis process and } \\
0.1 \mathrm{M} \mathrm{KOH} \text {, oxygen saturated } \\
10 \mathrm{mV} \cdot \mathrm{s}^{-1}, 1500 \mathrm{rpm}(0.1 \mathrm{M} \mathrm{KOH}+2.0 \mathrm{M} \mathrm{MeOH})\end{array}$ & $\begin{array}{l}J_{\mathrm{d}}=5.2 \mathrm{~mA} \cdot \mathrm{cm}^{-2} \\
\text { (Inactive in MeOH presence) } \\
E_{1 / 2}=0.675 \mathrm{~V} \text { vs. RHE }\end{array}$ & [39] \\
\hline $\begin{array}{l}\text { 3D-NCNT-900 (N-doped } \\
\text { carbon nanotubes) }\end{array}$ & $\begin{array}{l}\text { PPy nanotubes were synthesized by the chemical } \\
\text { oxidative polymerization of pyrrole, in the presence } \\
\text { of } \mathrm{FeCl}_{3} \text { as an oxidant, and p-toluene sulfonic acid } \\
(\mathrm{TsOH}) \text { as a dopant and } 0.1 \mathrm{M} \mathrm{KOH} \text {, } \\
\text { oxygen saturated, } 10 \mathrm{mV} \cdot \mathrm{s}^{-1}, 1600 \mathrm{rpm} \\
(0.1 \mathrm{M} \mathrm{KOH}+5.0 \mathrm{M} \mathrm{MeOH})\end{array}$ & $\begin{array}{l}J_{\mathrm{d}}=5.2 \mathrm{~mA} \cdot \mathrm{cm}^{-2} \\
\text { (Inactive in MeOH presence) } \\
E_{1 / 2}=0.707 \mathrm{~V} \text { vs. RHE }\end{array}$ & [40] \\
\hline $\begin{array}{l}\text { 3D-N-doped-TTF-700 } \\
\text { (thermalized triazine-based } \\
\text { framework) }\end{array}$ & $\begin{array}{l}\text { A nitrogen-containing molecule, terephthalonitrile, } \\
\text { as the basic building block and through first } \\
\text { trimerization into a } 2 \mathrm{D} \text { covalent triazine-based } \\
\text { framework and } 0.1 \mathrm{M} \mathrm{KOH} \text {, oxygen saturated; } \\
10 \mathrm{mV} \cdot \mathrm{s}^{-1}, 1600 \mathrm{rpm}\end{array}$ & $\begin{array}{l}J_{\mathrm{d}}=4.0 \mathrm{~mA} \cdot \mathrm{cm}^{-2} \\
E_{1 / 2}=0.767 \mathrm{~V} \text { vs. RHE }\end{array}$ & [41] \\
\hline
\end{tabular}

Among all carbon materials, graphene is the most promising for accommodating various nanoparticles to achieve high electron transport rate, electrolyte contact area and structural stability, all of which lead to markedly improved ORR performance. Replacing carbon with graphene in 
3D structures combined with M-N-doped-carbon further enhances their electrocatalytic activity and stability (M-N-doped-3D graphene). The effective dispersion of $\mathrm{Co}_{3} \mathrm{O}_{4}$ nanosheets among $3 \mathrm{D}$ graphene sheets was made via argon-plasma synthesis. The $\mathrm{Co}_{3} \mathrm{O}_{4}$ nanosheets formed strong bonds with graphene sheets enhancing its electrical conductivity and electrochemical activity. The kinetic analysis resulted a kinetic current density of $34 \mathrm{~mA} \cdot \mathrm{cm}^{-2}$ at $-0.75 \mathrm{~V}$ vs. RHE and a half-wave potential of $0.832 \mathrm{~V}$ vs. RHE. Additionally, a high stability was obtained as after 5.5 operational hours only $2 \%$ of its initial limiting current density was lost, while in the case of $\mathrm{Pt}(20 \mathrm{wt} \%) / \mathrm{C}$, ca $21 \%$ loss was detected [38].

The kinetic parameters (the available ones) of the electrocatalysts reported in the current review, along with the respective preparation methods are summarized in Table 1. It is observed that most of the electrocatalysts have also been investigated for the ORR in presence of methanol, as its crossover to cathode has been considered as one of the major reasons for the decay of ORR activity [3]. It is remarkable that each of them shows excellent tolerance to methanol, considering that just few years ago the main disadvantage of the non-precious electrocatalysts was related with their instability due to alcohol crossover [1,3].

It should be pointed out that the data given in literature are often problematic or misleading. For example, the limiting current density from RDE measurement varies considerably under the same conditions. According to Levich equation, the steady-state limiting current density for the $4 \mathrm{e}^{-}$ORR is ca $6.0 \mathrm{~mA} \cdot \mathrm{cm}^{-2}$ in a diluted electrolyte aqueous solution. The deviation observed in Table 1 should possibly be originated from several reasons. A negative deviation is caused by at least, but not limited, to the following reasons: (i) the poor quality of the fabricated electrode with an incomplete coverage of the electrocatalyst on the substrate; (ii) a mixed reaction pathway with both $2 \mathrm{e}^{-}$and $4 \mathrm{e}^{-}$charge transfer processes; (iii) poor electrocatalytic activity, and not mass transfer controlled steady state. A positive deviation, the other side of the coin, can also be found in literature (see Table 2), which is understandable as follows. The loading of the non-precious metal catalyst is generally pretty high, and thereby, the thickness of the "thin-film" electrode cannot be neglected any more. As such, the radial mass transfer should be considered for such "column-like" electrodes. Therefore, the comparison is sometimes tricky and should be cautious in practice. In our opinion, the normalized kinetic current density, other than the mass transfer-controlled current, should be used to benchmark the activity in future. Nevertheless, the data are summarized in this review (Tables 1-3), which are phenomenally used for reference.

On 2016, porous N-doped carbon nanotubes (NCNTs) with high surface area $\left(>1000 \mathrm{~m}^{2} \cdot \mathrm{g}^{-1}\right)$ are fabricated by $\mathrm{KOH}$ activation and pyrolysis of polypyrrole nanotubes. They exhibited excellent ORR electrocatalytic (those annealed at $900{ }^{\circ} \mathrm{C}$ ) performance and yielded a more positive onset potential, higher current density, and long-term operation stability in alkaline media, when compared with a commercially available $20 \mathrm{wt} \% \mathrm{Pt} / \mathrm{C}$ catalyst; this behaviour is mostly due to the synergetic effect between the dominant pyridinic/graphitic-N species and the porous tube structures. These metal-free porous nitrogen-doped carbon nanomaterials could be considered as potential alternatives to $\mathrm{Pt} / \mathrm{C}$ catalysts, for electrochemical energy conversion and storage [40].

2D materials, as the 3D ones, have also attracted increased interest, with graphitic carbon nitride $\left(\mathrm{g}-\mathrm{C}_{3} \mathrm{~N}_{4}\right)$ as a derivative graphene to be identified also as a good ORR electrocatalyst. More precisely, the development of porous organic networks, which stems from the polymerization of rigid organic molecules, offers the opportunity of 3D controllable structured electrocatalysts preparation [42]. Recently, Hao et al. [41] exploited the 2D structure of triazine-based framework (metal organic) and convert it to a 3D porous electrocatalyst. Its stability at $0.6 \mathrm{~V}$ vs. RHE was excellent as kept stable by $100 \%$ for $11 \mathrm{~h}$ of operation, as well as its tolerance in presence of $3.0 \mathrm{M}$ methanol. Moreover, its catalytic performance is considered high compared with the results reviewed in the present work, as its half-wave potential reached $0.767 \mathrm{~V}$ vs. RHE.

Zeolitic imidazolate framework (ZIF) constitutes another precursor used often for the preparation of $2 \mathrm{D} / 3 \mathrm{D}$ controllable structures More precisely, this is a zeolite-type nanoscale metal-organic 
framework (MOF), which is used as a self-sacrificing template as well as both carbon and nitrogen source [43]. A 2D carbon-based network electrocatalyst (Co-Al-LDH@ZIF67-800 ${ }^{\circ} \mathrm{C}$ ), consisting of well-defined metal-organic framework (MOF) arrays on layered double hydroxides (LHDs) exhibited a limiting current density of $5.2 \mathrm{~mA} \cdot \mathrm{cm}^{-2}$, with half-wave potential of $0.675 \mathrm{~V}$ vs. RHE; no reaction was observed in the presence of $2.0 \mathrm{M}$ methanol [39]. Moreover, the as-prepared electrocatalyst presented superior durability as it lost only $1 \%$ of its activity after $5.5 \mathrm{~h}$ of operation at $-0.5 \mathrm{~V}$ vs. RHE; under the same operation conditions, $\mathrm{Pt} / \mathrm{C}$ lost $40 \%$ of its activity [39].

Miner et al. [44] using as MOF hexa-iminotriphenylene (HITP) synthesized a tunable highly ordered 2D-structured ORR electrocatalyst material, $\mathrm{Ni}_{3}(\mathrm{HITP})_{2}$. However, according to RDE results it did not reach a plateau when examined in oxygen saturated $0.1 \mathrm{M} \mathrm{KOH}$ solution, at $2000 \mathrm{rpm}$. Therefore, for the enhancement of its ORR activity further investigation should be carried out.

In Figure 1, the long term stability comparison between the above-mentioned electrocatalysts is depicted. All the examined electrocatalysts are characterized by relatively good stability; after $10 \mathrm{~h}$, they lose less than $8 \%$ of their initial current density. Longer-term stability for $25 \mathrm{~h}$ is observed for 3D-structured Co-N-doped highly ordered macro-mesoporous carbon electrocatalyst [29]. To the best of our knowledge, this is the highest value of long-term stability, which is mostly attributed to the 3D as well as to the macro and mesoporous structures.

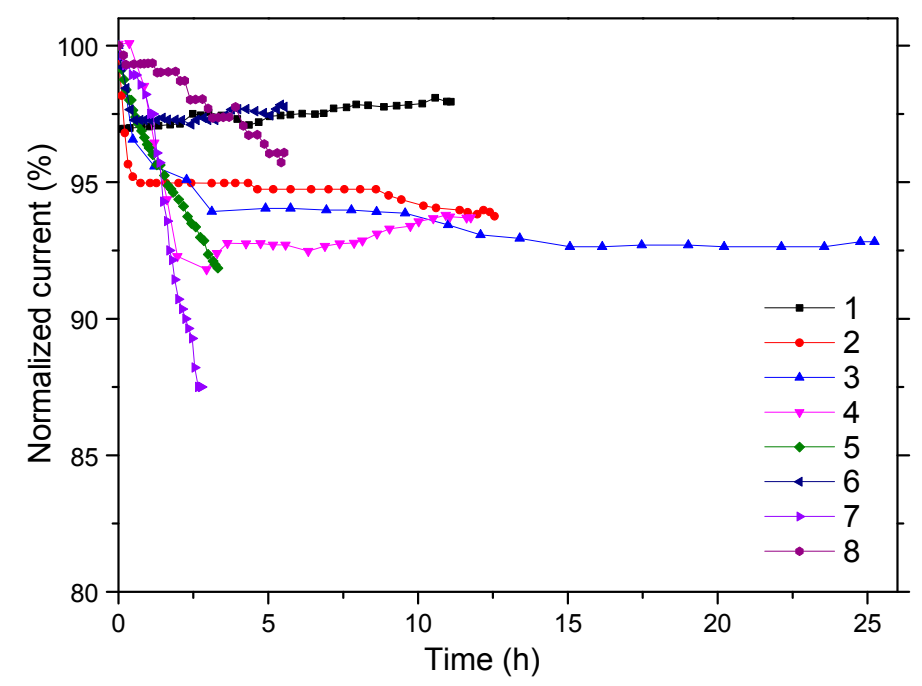

Figure 1. Comparison of stability of 3D-structured non-precious carbon based electrocatalysts: (1) NHCs (N-doped hierarchically carbon) (at $0.5 \mathrm{~V}$ vs. RHE) [27]; (2) 3D-HPC-N (N-doped-3Dhierarchically porous carbon materials)-850 (at $0.55 \mathrm{~V}$ vs. RHE) [28]; (3) 3D Co-N-OMMC-0.6 $\left(\mathrm{Co}\left(\mathrm{NO}_{3}\right)_{2} \cdot 6 \mathrm{H}_{2} \mathrm{O}\right.$ ) (ordered macro-mesoporous carbon) (at $0.6 \mathrm{~V}$ vs. RHE) [29]; (4) 3D hierarchical porous- $\mathrm{CoFe}_{2} \mathrm{O}_{4}$ hollow nanospheres (at $0.56 \mathrm{~V}$ vs. RHE) [34]; (5) $\mathrm{Mn}_{x} \mathrm{Co}_{3 x} \mathrm{O}_{4}$ ( $x=0.4$ ) [36]; (6) Nanosheet $\mathrm{Co}_{3} \mathrm{O}_{4}$-doped-graphene-3D [38]; (7) 2D-CoAl-LDH@ZIF-67-800 (LDH: layered double hydroxides, ZIF: zeolitic imidazolate framework [39]; and (8) 3D-N-doped-TTF (thermalized triazine-based framework)-700 (at $0.6 \mathrm{~V}$ vs. RHE) [41].

The half-wave potential $\left(E_{1 / 2}\right)$ is conventionally used for the comparison of the ORR activity between different electrocatalysts [36]. To evaluate the catalytic activities of the electrocatalysts listed in Table 1, the half-wave potentials are depicted in Figure 2. As can be seen, 3D-structured Co-N-doped highly ordered macro-mesoporous carbon electrocatalyst [29] and 3D nanosheet $\mathrm{Co}_{3} \mathrm{O}_{4}$-doped-graphene [38] exhibit the same half-wave potential values ( 0.83 V vs. $\left.\mathrm{RHE}\right)$. The specific half-wave value is almost the same as that of $\mathrm{Pt}$ (ca $0.8 \mathrm{~V}$ vs. RHE). However, they differ in their kinetic current values: the 3D nanosheets $\mathrm{Co}_{3} \mathrm{O}_{4}$-doped-graphene [38] exhibited a kinetic current density of $34 \mathrm{~mA} \cdot \mathrm{cm}^{-2}$ at $0.75 \mathrm{~V}$ vs. RHE, while the 3D-structured Co-N-doped highly ordered macro-mesoporous carbon of $23.2 \mathrm{~mA} \cdot \mathrm{cm}^{-2}$. 


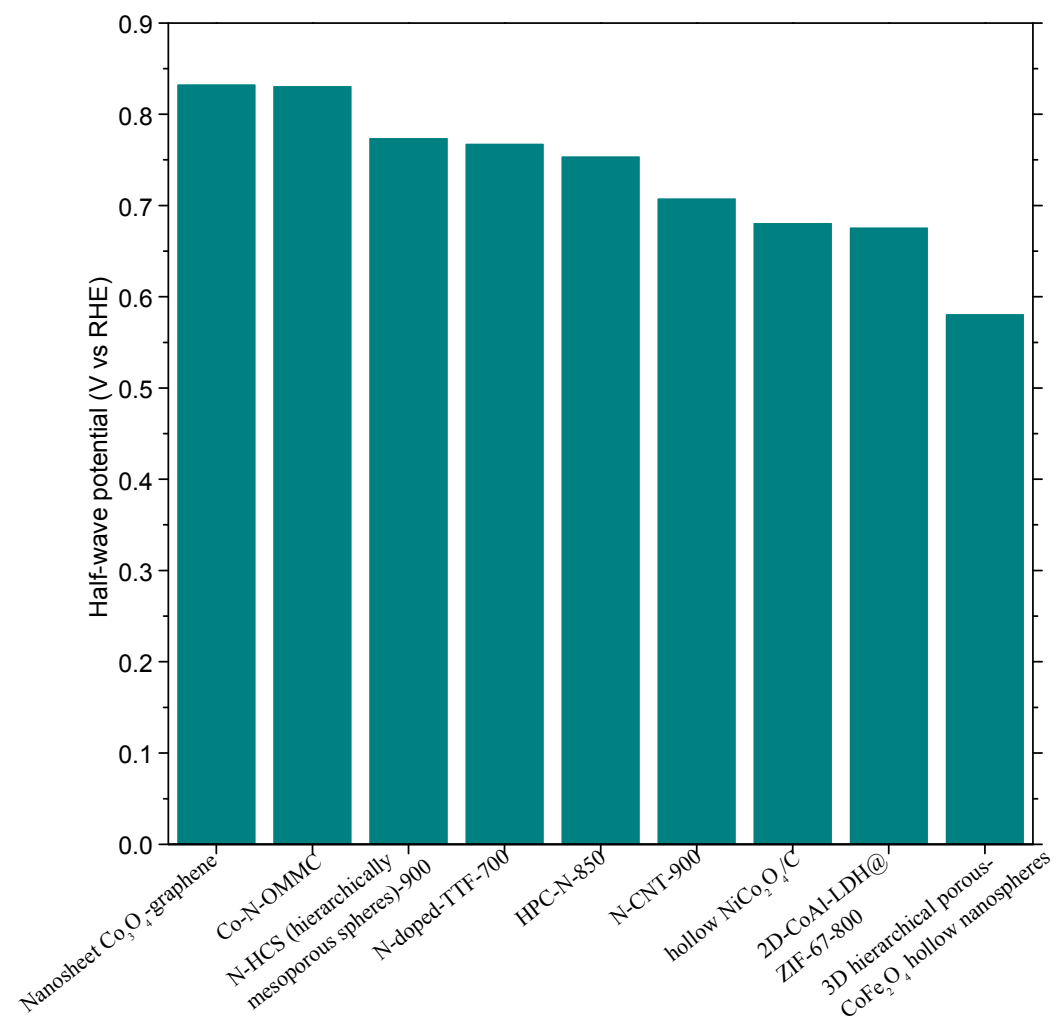

Figure 2. Comparison of half-wave potential (V vs. RHE). (References from left to right column: [38], [29], [27], [41], [28], [40], [35], [39], [34]).

\section{Hybrid (Metal Oxide-Nitrogen-Carbon) Electrocatalysts}

Despite the fact that, in acidic media, the transition metal oxides exhibit very low ORR activity and insufficient stability, in alkaline media, they exhibit high activity, mostly due to the oxygen-containing groups [45]. The key for their enhanced activity is the amplification of their conductivity by integrating their conductive matrix, forming the as-called hybrid materials; metal oxide-N-C [46].

In Table 2, along with their respective kinetic parameters, the most active ORR hybrid electrocatalysts are listed. Most of them seem to present higher ORR activity than the 2D or 3D electrocatalysts (Table 1). Characteristic is that all authors report higher limiting current and more positive onset and half-wave potential values than $\mathrm{Pt} / \mathrm{C}$ electrocatalyst (Table 2). Additionally, most of those that were examined for methanol tolerance were found totally unaffected by methanol's presence.

Table 2. Non-precious hybrid ORR electrocatalysts.

\begin{tabular}{|c|c|c|c|}
\hline Catalyst & Preparation Method and Experimental Conditions & $\begin{array}{l}\text { Limiting Current }\left(J_{\mathrm{d}} ; \mathrm{d}=\text { disc }\right) \text {, } \\
\text { Kinetic Current Density }\left(J_{\mathrm{k}}\right) \text {, } \\
\left.\text { Half Wave Potential }\left(E_{1 / 2}\right)\right)\end{array}$ & Reference \\
\hline $\begin{array}{l}\mathrm{Co}_{0.03} @ \mathrm{CoO}-\mathrm{N}-\text { doped } \\
\text { graphene carbon } \\
\text { shells- } 800\end{array}$ & $\begin{array}{l}\text { Introduction of metal precursor (cobalt nitrate) to } \\
\text { sucrose and urea followed by pyrolyzing and } \\
0.1 \mathrm{M} \mathrm{KOH} \text {, oxygen saturated, } 10 \mathrm{mV} \cdot \mathrm{s}^{-1}, 1600 \mathrm{rpm} \text {, } \\
(0.1 \mathrm{M} \mathrm{KOH}+0.5 \mathrm{M} \mathrm{MeOH})\end{array}$ & $\begin{array}{l}J_{\mathrm{d}}=4.1 \mathrm{~mA} \cdot \mathrm{cm}^{-2} \\
\text { (Inactive in } \mathrm{MeOH} \text { presence) } \\
E_{1 / 2}=0.81 \mathrm{~V} \text { vs. RHE }\end{array}$ & [47] \\
\hline BCN-2.5 at. $\%-1000$ & $\begin{array}{l}\text { CVD synthesis of BCN sheets by thermally } \\
\text { decomposing solid } \mathrm{B} C \text { - and N-containing precursors } \\
\text { at normal pressure and } 0.1 \mathrm{M} \mathrm{KOH} \text {, oxygen saturated, } \\
10 \mathrm{mV} \cdot \mathrm{s}^{-1}, 1600 \mathrm{rpm},(0.1 \mathrm{M} \mathrm{KOH}+2.0 \mathrm{M} \mathrm{MeOH})\end{array}$ & $\begin{array}{l}J_{\mathrm{d}}=6.0 \mathrm{~mA} \cdot \mathrm{cm}^{-2} \\
\text { (Inactive in MeOH presence) } \\
E_{1 / 2}=0.707 \mathrm{~V} \mathrm{vs} . \text { RHE } \\
J_{\mathrm{k}}=26.62 \mathrm{~mA} \cdot \mathrm{cm}^{-2}\end{array}$ & [48] \\
\hline $\begin{array}{l}\text { CoAl-LDHs (layered } \\
\text { double hydroxide) } / \mathrm{rGO} \\
\text { (reduced graphene } \\
\text { oxide) }\end{array}$ & $\begin{array}{l}\text { Grow CoAl-LDHs on the surface of GO in-situ via } \\
\text { coprecipitation and subsequently hydrothermal } \\
\text { treatment and } 0.1 \mathrm{M} \mathrm{KOH} \text {, oxygen saturated, } \\
10 \mathrm{mV} \cdot \mathrm{s}^{-1}, 1600 \mathrm{rpm}\end{array}$ & $\begin{array}{l}J_{\mathrm{d}}=4.8 \mathrm{~mA} \cdot \mathrm{cm}^{-2} \\
E_{1 / 2}=0.853 \mathrm{~V} \text { vs. RHE }\end{array}$ & [49] \\
\hline
\end{tabular}


Table 2. Cont.

\begin{tabular}{|c|c|c|c|}
\hline Catalyst & Preparation Method and Experimental Conditions & $\begin{array}{l}\text { Limiting Current }\left(J_{\mathrm{d}} ; \mathrm{d}=\text { disc }\right) \text {, } \\
\text { Kinetic Current Density }\left(J_{\mathrm{k}}\right) \\
\left.\text { Half Wave Potential }\left(E_{1 / 2}\right)\right)\end{array}$ & Reference \\
\hline $\begin{array}{l}\text { Co II -A-rG-O } \\
\text { (hybrid-ammonium) } \\
\text { hydroxide-reduced } \\
\text { graphene) }\end{array}$ & $\begin{array}{l}\text { Synthesis at room temperature of archetypical hybrid } \\
\text { materials consisting of cobalt-based organometallic } \\
\text { complexes }\left(\left[\mathrm{Co}(\mathrm{acac})_{2}\right], \text { acac }=\text { acetylacetonate) }\right. \\
\text { coordinated to } \mathrm{N}-\mathrm{doped} \text { graphenes and } 0.1 \mathrm{M} \mathrm{KOH} \text {, } \\
\text { oxygen saturated, } 10 \mathrm{mV} \cdot \mathrm{s}^{-1}, 1600 \mathrm{rpm}\end{array}$ & $\begin{array}{l}J_{\mathrm{d}}=5.4 \mathrm{~mA} \cdot \mathrm{cm}^{-2} \\
E_{1 / 2}=0.81 \mathrm{~V} \mathrm{vs} . \mathrm{RHE} \\
J_{\mathrm{k}}=8.9 \mathrm{~mA} \cdot \mathrm{cm}^{-2} \text { at } 0.8 \mathrm{~V} \mathrm{vs} . \mathrm{RHE}\end{array}$ & {$[50]$} \\
\hline $\begin{array}{l}\mathrm{Co} / \mathrm{N}-\mathrm{HCOs} \\
\text { (Co/N-co-doped } \\
\text { hollowed-out carbon } \\
\text { octahedrons) }\end{array}$ & $\begin{array}{l}\text { Octahedral Co(II) complex with } \\
\text { 2,6-bis(benzimidazol-2-yl)pyridine (BBP) as the } \\
\text { precursor and } 0.1 \mathrm{M} \mathrm{KOH} \text {, oxygen saturated, } \\
10 \mathrm{mV} \cdot \mathrm{s}^{-1}, 1600 \mathrm{rpm}\end{array}$ & $\begin{array}{l}J_{\mathrm{d}}=4.9 \mathrm{~mA} \cdot \mathrm{cm}^{-2} \\
E_{1 / 2}=0.81 \mathrm{~V} \text { vs. } \mathrm{RHE}\end{array}$ & {$[51]$} \\
\hline $\begin{array}{l}\mathrm{Co}(\mathrm{OH})_{2} \text {-nanoplate/ } \\
\mathrm{N}-\mathrm{RGO}(\mathrm{N} \text {-doped } \\
\text { reduced graphene oxide) }\end{array}$ & $\begin{array}{l}\text { Hydrothermal method and } 0.1 \mathrm{M} \mathrm{KOH} \text {, } \\
\text { oxygen saturated, } 5 \mathrm{mV} \cdot \mathrm{s}^{-1}, 1600 \mathrm{rpm}\end{array}$ & $\begin{array}{l}J_{\mathrm{d}}=4.7 \mathrm{~mA} \cdot \mathrm{cm}^{-2} \\
E_{1 / 2}=0.66 \mathrm{~V} \text { vs. RHE }\end{array}$ & {$[52]$} \\
\hline $\begin{array}{l}\text { N/Co-doped } \\
\text { PCP(porous carbon } \\
\text { polyhedron)/NRGO }\end{array}$ & $\begin{array}{l}\text { Pyrolysis of graphene oxide-supported cobalt-based } \\
\text { zeolitic imidazolate-framework and } 0.1 \mathrm{M} \mathrm{KOH} \text {, } \\
\text { oxygen saturated, } \\
5 \mathrm{mV} \cdot \mathrm{s}^{-1}, 1600 \mathrm{rpm}(0.1 \mathrm{M} \mathrm{KOH}+3.0 \mathrm{M} \mathrm{MeOH})\end{array}$ & $\begin{array}{l}J_{\mathrm{d}}=7.8 \mathrm{~mA} \cdot \mathrm{cm}^{-2} \\
\text { (Inactive even after of } 48 \mathrm{~h} \text { ) } \\
J_{\mathrm{k}}=11.6 \mathrm{~mA} \cdot \mathrm{cm}^{-2} \text { at } 0.7 \mathrm{~V} \mathrm{vs} . \mathrm{RHE} \\
E_{1 / 2}=0.93 \mathrm{~V} \mathrm{vs} . \text { RHE }\end{array}$ & {$[53]$} \\
\hline $\begin{array}{l}\mathrm{CoCN} @ \mathrm{CoO}_{x}(18) / \mathrm{NG} \\
\text { (cobaltcarbonitride/ } \\
\text { nitrogen doped } \\
\text { graphene) }\end{array}$ & $\begin{array}{l}\text { High temperature ammonia nitridation method and } \\
0.1 \mathrm{M} \mathrm{KOH} \text {, oxygen saturated, } 10 \mathrm{mV} \cdot \mathrm{s}^{-1}, 1600 \mathrm{rpm} \text {, } \\
(0.1 \mathrm{M} \mathrm{KOH}+1.0 \mathrm{M} \mathrm{MeOH})\end{array}$ & $\begin{array}{l}J_{\mathrm{d}}=5.9 \mathrm{~mA} \cdot \mathrm{cm}^{-2} \\
\text { (Inactive in } \mathrm{MeOH} \text { presence) } \\
E_{1 / 2} 0.763 \mathrm{~V} \text { vs. RHE }\end{array}$ & {$[54]$} \\
\hline C-CZ-4(N-CNTs)-1000 & $\begin{array}{l}\text { In situ growth of metal-organic frameworks (ZIF- } 8) \text { on } \\
\text { carbon nanotubes, followed by pyrolysis and } 0.1 \mathrm{M} \\
\mathrm{KOH} \text {, oxygen saturated, } 5 \mathrm{mV} \cdot \mathrm{s}^{-1}, 1600 \mathrm{rpm}(0.1 \mathrm{M} \\
\mathrm{KOH}+1.0 \mathrm{M} \mathrm{MeOH})\end{array}$ & $\begin{array}{l}J_{\mathrm{d}}=6.0 \mathrm{~mA} \cdot \mathrm{cm}^{-2} \\
\text { (Inactive in } \mathrm{MeOH} \text { presence) } \\
E_{1 / 2}=0.887 \mathrm{~V} \text { vs. RHE }\end{array}$ & [55] \\
\hline $\begin{array}{l}\text { Bamboo-like } \mathrm{CNT} / \mathrm{Fe}_{3} \mathrm{C} \\
\text { nanoparticle hybrids- } 800\end{array}$ & $\begin{array}{l}\text { Annealing a mixture of PEG-PPG-PEG Pluronic P123, } \\
\text { melamine, and } \mathrm{Fe}\left(\mathrm{NO}_{3}\right)_{3} \text { at } 800^{\circ} \mathrm{C} \text { in } \mathrm{N}_{2} \text { and } \\
0.1 \mathrm{M} \mathrm{KOH} \text {, oxygen saturated, } 10 \mathrm{mV} \cdot \mathrm{s}^{-1}, 1600 \mathrm{rpm}\end{array}$ & $\begin{array}{l}J_{\mathrm{d}}=4.0 \mathrm{~mA} \cdot \mathrm{cm}^{-2} \\
E_{1 / 2}=0.861 \mathrm{~V} \text { vs. RHE }\end{array}$ & [56] \\
\hline $\begin{array}{l}\mathrm{Co}_{3} \mathrm{O}_{4} / \mathrm{NG} \\
\text { (nitrogen-doped } \\
\text { graphene) }\end{array}$ & $\begin{array}{l}\text { Hydrothermal reaction of } \mathrm{GO}, \mathrm{MR} \text {, and } \mathrm{CoCl}_{2} \\
\text { followed by a two-step heat treatment and } 0.1 \mathrm{M} \mathrm{KOH} \text {, } \\
\text { oxygen saturated, } 10 \mathrm{mV} \cdot \mathrm{s}^{-1}, 1600 \mathrm{rpm}\end{array}$ & $\begin{array}{l}J_{\mathrm{d}}=4.6 \mathrm{~mA} \cdot \mathrm{cm}^{-2} \\
E_{1 / 2}=0.74 \mathrm{~V} \mathrm{vs} . \mathrm{RHE}\end{array}$ & [57] \\
\hline $\begin{array}{l}\text { CoNPs@NG } \\
\text { (nitrogen-doped } \\
\text { graphene) }\end{array}$ & $\begin{array}{l}\text { Thermal condensation of biomass and corresponding } \\
\text { metal salts and } 0.1 \mathrm{M} \mathrm{KOH} \text {, oxygen saturated, } \\
10 \mathrm{mV} \cdot \mathrm{s}^{-1}, 1600 \mathrm{rpm}(0.1 \mathrm{M} \mathrm{KOH}+1.0 \mathrm{M} \mathrm{MeOH})\end{array}$ & $\begin{array}{l}J_{\mathrm{d}}=7.2 \mathrm{~mA} \cdot \mathrm{cm}^{-2} \\
E_{1 / 2}=1.01 \mathrm{~V} \text { vs. RHE }\end{array}$ & [58] \\
\hline $\mathrm{C}(\mathrm{PANI}) / \mathrm{Mn}_{2} \mathrm{O}_{3}$ & $\begin{array}{l}\text { Surface protected calcination processes and } \\
0.1 \mathrm{M} \mathrm{KOH} \text {, oxygen saturated, } 10 \mathrm{mV} \cdot \mathrm{s}^{-1}, 1600 \mathrm{rpm}\end{array}$ & $\begin{array}{l}J_{\mathrm{d}}=5.61 \mathrm{~mA} \cdot \mathrm{cm}^{-2} \\
E_{1 / 2}=0.784 \mathrm{~V} \text { vs. RHE }\end{array}$ & [59] \\
\hline
\end{tabular}

In general, Metal-N-doped carbon (especially graphene)-based electrocatalysts are preferred as conductive matrix materials. They are more positive than the others' hybrid materials, and half-wave potential as well as onset potential (Figure 3) make them more plausible candidate for cathodes. Namely, N/Co-doped graphene-type electrocatalyst (CoNPs@NG) [58] performed half-wave potential $\left(E_{1 / 2}\right)$ of $1.01 \mathrm{~V}$ vs. RHE; about $0.19 \mathrm{~V}$ more positive than $\mathrm{Pt} / \mathrm{C}^{\prime} \mathrm{s}$, the value of which is usually around $0.8 \mathrm{~V}$ vs. RHE. Its high activity was attributed to the growth of N-Co nanocrystal through the graphene plane and not at its edges, permitting the formation of a higher amount of active sites available to the reactants. Its special structure also offered very good stability performance as it is indicated from Figure 4. After ca $10 \mathrm{~h}$ of operation, only about $8 \%$ of current decay was observed. Remarkably, the same catalyst also presented good long-term stability in acidic environment, preserving $91 \%$ of its initial activity after $8.5 \mathrm{~h}$ of operation.

A novel hybrid electrocatalyst with reduced nitrogen-doped graphene/cobalt embedded porous carbon polyhedron was developed by Hou et al. [53]. A four-electron pathway was activated, performing $E_{1 / 2}=0.93 \mathrm{~V}$ vs. RHE. Except for its excellent activity, this catalyst exhibited also a good durability, as after $5.5 \mathrm{~h}$ operation, its initial activity decreased by $14.5 \%$ in comparison with $\mathrm{Pt} / \mathrm{C}$, whose initial activity was reduced more than $30 \%$ for the same operation period. Its excellent activity was mainly attributed to the following factors: (i) the doping effect of $\mathrm{N}$ and $\mathrm{Co}$; (ii) the porous structure; and (iii) the good contact between N/Co-doped carbon polyhedron and nitrogen-doped reduced graphene oxide. 


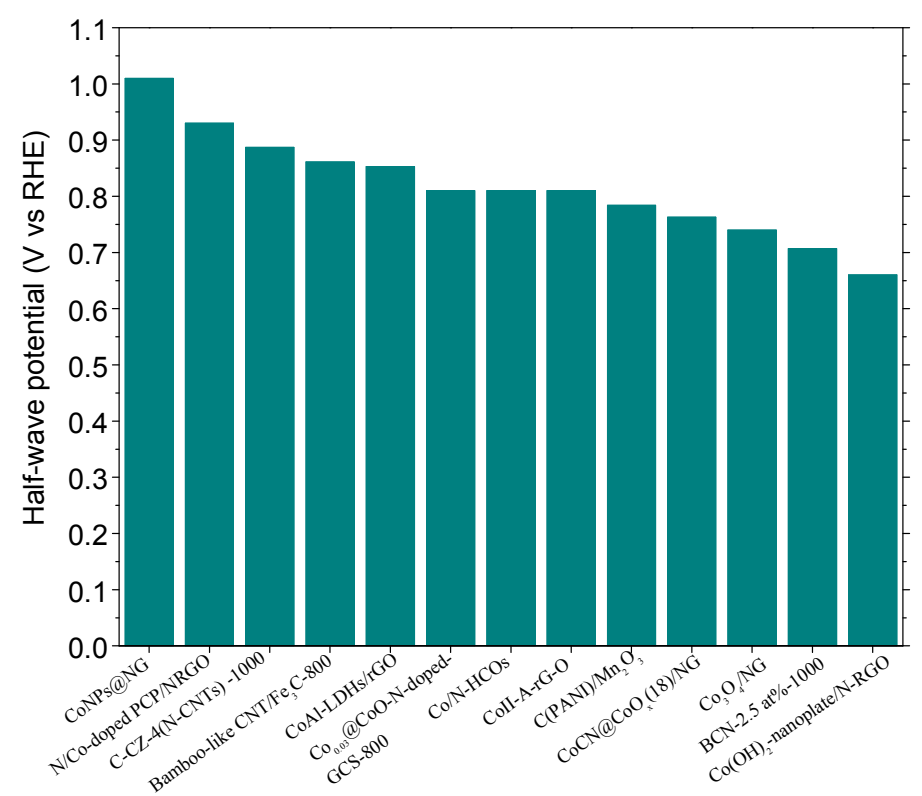

Figure 3. Comparison of half-wave potentials. (References from left to right bar: [58], [53], [55], [56], [49], [47], [50], [51], [59], [54], [57], [48], [52]).

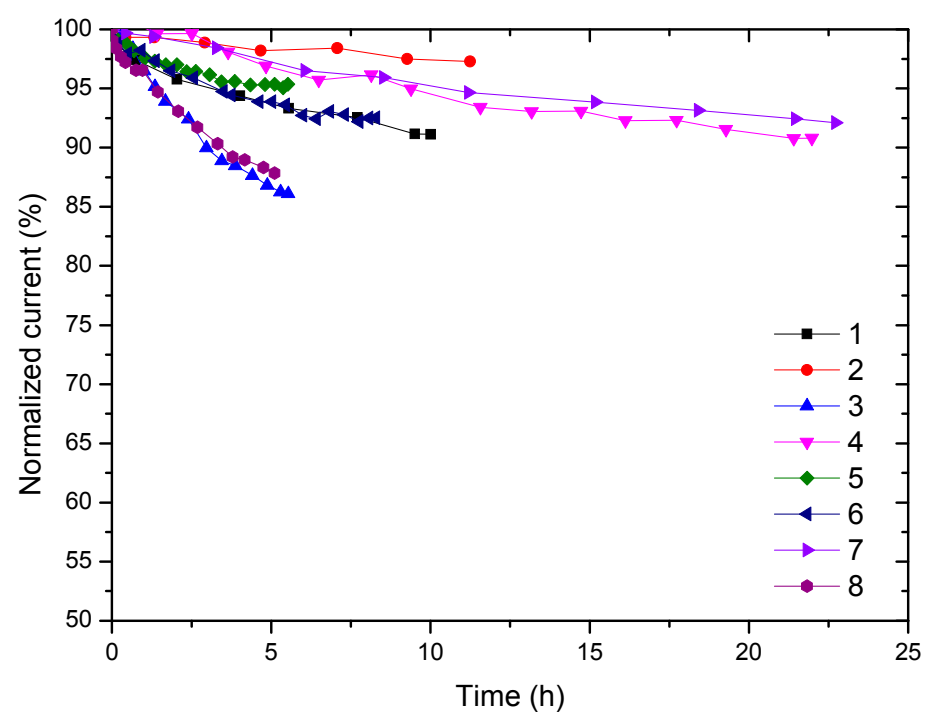

Figure 4. Long-term stability curves of hybrid materials: (1) $\mathrm{Co}_{0.03} @ \mathrm{CoO}-\mathrm{N}$-doped graphene carbon shells-800 (at $-0.4 \mathrm{~V}$ vs. SCE) [47]; (2) Two-dimensional materials based on ternary system of $\mathrm{B}, \mathrm{C}$ and $\mathrm{N}\left(\mathrm{B}(2\right.$ at $\%) \mathrm{N}(5$ at $\%) \mathrm{G}-1000{ }^{\circ} \mathrm{C}$ ) [48]; (3) N/Co-doped PCP//NRGO (at $-0.25 \mathrm{~V}$ vs. $\mathrm{Ag} / \mathrm{AgCl}$ ) [53]; (4) $\mathrm{CoCN} @ \mathrm{CoO}_{x}(18) / \mathrm{NG}$ (cobalt carbonitride/nitrogen doped graphene) [54]; (5) $\mathrm{Co}_{3} \mathrm{O}_{4} / \mathrm{NG}$ (nitrogen-doped graphene) (at -0.36 V vs. SCE) [57]; (6) CoNPs@NG (nitrogen-doped graphene) [58]; (7) C(PANI) $/ \mathrm{Mn}_{2} \mathrm{O}_{3}$ (hybrid) (at $0.8 \mathrm{~V}$ vs. RHE) [59]; and (8) $\mathrm{CoO} / \mathrm{MnO}_{2} / \mathrm{RGO}$ (reduced graphene oxide) (at $0.66 \mathrm{~V}$ vs. RHE) [60].

$\mathrm{N}$-containing metal organic frameworks, like in the case of three-dimensional category, can deliver really good ORR electrocatalytic activity. An in in-situ grown metal-organic framework (MOF)/carbon nanotube (CNT) composite, instead of a surface grown one, was prepared and tested by Ge et al. [55], using ZIF-8 as precursor and by pyrolyzing the catalyst at $1000^{\circ} \mathrm{C}$. The as-prepared electrocatalyst reached a half-wave potential of $0.887 \mathrm{~V}$ vs. RHE and a limiting current of $6.0 \mathrm{~mA} \cdot \mathrm{cm}^{-2}$, remaining stable even in the presence of $1 \mathrm{M} \mathrm{CH}_{3} \mathrm{OH}$. 
Yang et al. [56] used, in their turn, melamine as natural source of nitrogen, synthesizing bamboo-like carbon nanotube $\mathrm{Fe}_{3} \mathrm{C}$ NPs hybrid electrocatalyst, which also exhibited $E_{1 / 2}=0.861 \mathrm{~V}$ vs. RHE as well as excellent tolerance towards methanol. The $\mathrm{Co} / \mathrm{N}$-doped graphene hybrid catalyst, prepared by using urea as natural nitrogen source, in combination with sucrose and cobalt nitrate performed a half-wave potential of $0.81 \mathrm{~V}$ vs. RHE [47]. Moreover, the as-prepared electrocatalyst after $10 \mathrm{~h}$ operation at $0.4 \mathrm{~V}$ lost only $8 \%$ of its initial activity.

Urea with boric acid and polyethylene glycol were used for the preparation of B-N-co-doped graphite layers [48]. The obtained ORR kinetic current density was ca $27.0 \mathrm{~mA} \cdot \mathrm{cm}^{-2}$, while its half-wave potential was very satisfactory; ca $0.707 \mathrm{~V}$ vs. RHE. Its activity remained unaffected in the presence of methanol $(2.0 \mathrm{M})$ and its stability was very good, unchanged for $8.5 \mathrm{~h}$, at $0.853 \mathrm{~V}$ vs. RHE, while $\mathrm{Pt}(20 \mathrm{wt} \%) / \mathrm{C}$, examined under the same experimental conditions, decreased by $20 \%$. In hybrid-BCNs the extra electrons of nitrogen and the empty orbital of boron are connected into the carbon matrix, changing the electron density distribution of carbon [60-62].

Moreover, sandwich-like hybrid porous $\mathrm{CO}_{3} \mathrm{O}_{4}$ nanospheres and $\mathrm{N}$-doped graphene using melamine as precursor were prepared by Zhang et al. [57]. By using melamine instead of urea or ammonia as nitrogen source, nitrogen NPs helped being attached not only at the edges of the graphene, but also in its inert areas; cobalt in each turn is intruded in the inert part of graphene providing much more active area. However, $\mathrm{Co}_{3} \mathrm{O}_{4} / \mathrm{NG}$ (nitrogen-doped graphene) exhibited good and close to Pt's half-wave potential, ca $0.74 \mathrm{~V}$ vs. RHE, indicating that it possesses high ORR activity. Meanwhile, its stability was good since after $5.5 \mathrm{~h}$ durability test at $0.913 \mathrm{~V}$ vs. RHE lost only $6 \%$ of its activity, while Pt/C lost 30\% [57].

Additionally, Chao et al. [51] tried to make more environmentally friendly the preparation processes of hybrid materials by using inexpensive $\mathrm{Co}\left(\mathrm{CH}_{3} \mathrm{COO}\right)_{2} \cdot 4 \mathrm{H}_{2} \mathrm{O}$ and 2,6-bis(benzimidazol-2-yl)pyridine (BBP) as raw materials. As described above, most of the fabrication methods of hybrid materials include multiple and relatively expensive processes. The result was a hollowed-out octahedral $\mathrm{Co} / \mathrm{N}$-co-doped carbon electrocatalyst that also performed a half-wave potential close to $0.81 \mathrm{~V}$ vs. RHE, and a limiting current density of $4.9 \mathrm{~mA} \cdot \mathrm{cm}^{-2}$. Its activity remained almost constant even after 8000 cycles from 0 to $1.2 \mathrm{~V}$, showing additionally remarkable methanol tolerance [51].

Among the investigated $\mathrm{N}$-containing precursors, polyaniline (PANI) is commonly used for the preparation of N-doped carbon electrocatalysts. The combination of PANI's aromatic rings and the $\mathrm{N}$-containing groups result in highly efficient ORR hybrid materials [63]. Recently, Cao et al. [59] reported half-wave potential of $0.784 \mathrm{~V}$ vs. RHE and $23 \mathrm{~h}$ long-term stability, at mesoporous hybrid shell of carbonized polyaniline $\mathrm{Mn}_{2} \mathrm{O}_{3}\left(\mathrm{C}_{\mathrm{PANI}} / \mathrm{Mn}_{2} \mathrm{O}_{3}\right)$ electrocatalyst. Their high activity and excellent stability was believed to be related with: (i) the high specific surface area; (ii) the surface oxidation state of $\mathrm{Mn}$; and (iii) the composition codependent behavior $\left(\mathrm{Mn}_{2} \mathrm{O}_{3}\right.$ and $\mathrm{C}_{\text {PANI }}$ are strongly dependent on each other). Hybrid materials have also been developed in order to improve the density of $\mathrm{N}$-doped carbon electrocatalysts. The low density, observed in many N-doped carbons, leads to a thick electrode layer with reduced mass transfer ability $[63,64]$. By increasing the density of the carbon structure the volumetric ORR activity increases too.

Recently, N-doped reduced graphene oxide materials have attracted much interest due to their ability to increase electrocatalytic activity of the simple N-doped graphene electrocatalyst [65-67]. In N-doped graphene, it has been found that oxygen groups are responsible for the formation of the $\mathrm{C}-\mathrm{N}$ bonds, increasing the conductivity of carbons. The reduction of $\mathrm{N}$-doped graphene increases the oxygen groups and consequently the electronic-conductivity; reduced graphene oxide exhibit n-type electron doping behavior.

The introduction of metal oxides into $\mathrm{N}$-doped graphene sheets, in order to form the hybrid material, can be processed through the following two-ways: (i) on the surface of the sheets; or (ii) through the plane of the graphene nanosheets. The second approach results in a better 
dispersion and higher stability of the NPs, giving the opportunity of exploiting both sides of graphene sheet $[67,68]$.

According to Figure 3, Co II-A-rG-O (hybrid-ammonium hydroxide-reduced graphene) performed the same ORR activity, giving also $0.81 \mathrm{~V}$ vs. RHE half-wave potential. Han et al. [50] proved that the high hybrid materials' activity toward ORR is attributed to the coordination of the modified carbon with the organometallic molecules. More precisely, the Co atom is coordinated in a square planar arrangement and an additional $\mathrm{N}$-atom (or $\mathrm{N}$ containing aromatic ring) at an axial position, to two acetylacetonate ligands.

$\mathrm{Co}_{3} \mathrm{Mn}-\mathrm{CO}_{3}-\mathrm{LDH} / \mathrm{RGO}$ electrocatalyst exhibited that its relative activity maintained $87 \%$ of its initial value, while in the case of $\mathrm{Pt} / \mathrm{C}$ at $82 \%$ [60].

A different geometrical hybrid electrocatalyst was developed by Zhan et al. [52], compounding hexagonal $\mathrm{Co}(\mathrm{OH})_{2}$ nanoplates with nitrogen-doped reduced graphene oxide. According to the authors, its good performance $\left(0.66 \mathrm{~V}\right.$ vs. RHE) is attributed to the nanosizing of $\mathrm{Co}(\mathrm{OH})_{2}$ and the synergistic interaction between $\mathrm{Co}(\mathrm{OH})_{2}$ and $\mathrm{N}-\mathrm{rGO}$. After $4 \mathrm{~h}$ of operation at $(-0.7 \mathrm{~V})$, its activity remained stable and the same with that of $(20 \mathrm{wt} \%) \mathrm{Pt} / \mathrm{C}$.

Additionally, the combination of layered double hydroxides (LDHs) with metal oxides results in highly efficient ORR electrocatalysts. The LDHs' more positive charge and their good long-term stability in alkaline environment make them advantageous and promising. The CoAl-LDHs on reduced graphene oxide support at the optimum ratio $\left(w_{\mathrm{CoAl}-\mathrm{LDHs}} / w_{\mathrm{GO}}=1: 5\right)$ performed $0.853 \mathrm{~V}$ vs. RHE half-wave potential, presenting no reaction in the presence of methanol (3.0 M) [49]. Moreover, it exhibited very stable behavior after $2.5 \mathrm{~h}$ operation at $-0.4 \mathrm{~V}$ without losing its activity. It was found that the presence of LDHs improved the electrons transfer, while the reduced graphene oxide has been considered as the hydrogen peroxide cleaner. Thus, the synergetic effect of those two factors lead to a really effective ORR electrocatalyst [49].

Zhao et al. [69] prepared and tested, a new type of cost-effective artificial oxygen-evolving complex (OEC) rather active for the ORR catalysts based on cobalt-phosphate (Co-Pi). More precisely, $\mathrm{Co}-\mathrm{Pi} \mathrm{OEC}$ anchoring on reduced graphite oxide $(\mathrm{rGO})$ nanosheet is shown to possess dramatically improved electrocatalytic activity. It was suggested that rGO serves as "peroxide cleaner" in enhancing the electrocatalytic behavior.

A new hybrid catalyst in the form of core-shell type, $\mathrm{CoCN}$ (carbonnitirde)@ $\mathrm{CoO}_{x} \mathrm{NPs}$, supported on N-doped graphene was designed for the ORR in an alkaline solution [54]. The oxide $2 \mathrm{~nm}$ thin layer $\left(\mathrm{CoO}_{x}\right)$ played a protective role preventing the oxidation corrosion of $\mathrm{CoCN}$. This electrocatalyst presented a low half-wave potential $\left(E_{1 / 2}=0.763 \mathrm{~V}\right.$ vs. RHE) compared to the other hybrid materials, but significantly high stability, losing only $10 \%$ of its initial reduction activity after $20 \mathrm{~h}$ of operation; under the same operational conditions, $\mathrm{Pt} / \mathrm{C}$ lost $\sim 30 \%$ of its activity. Its methanol tolerance was also high, as no any reaction was observed in $1.0 \mathrm{M}$ methanol concentration.

By comparing Figures 1 and 4, it can be deduced that hybrid materials exhibit a higher long-term stability performance during the ORR process. Among the examined hybrid electrocatalysts, the mesoporous hybrid shell of carbonized polyaniline $\mathrm{Mn}_{2} \mathrm{O}_{3}\left(\mathrm{C}_{\mathrm{PANI}} / \mathrm{Mn}_{2} \mathrm{O}_{3}\right)$ [59] and the $\mathrm{CoCN}$ (carbonnitirde)@ $\mathrm{CoO}_{x}$ supported on the graphene maintained more than $90 \%$ of their initial activity for about $20 \mathrm{~h}$ of operation [54]; both electrocatalysts have mesoporous core-shell structure offering more active sites and mass transfer. Thus, the strategy of intervening in carbon nanostructure by deliberately introducing in its main structure metal-organic frameworks develops hybrid materials/electrocatalysts. This strategy, according to the current review, has proven the most efficient one. Another, third, strategy of improving electrocatalytic activity of the non-precious metals concerns with the use of different nitrogen sources, as will be discussed below.

\section{Alternative Raw Materials}

Increasing homogeneity by the aid of doping constitutes another strategy adopted for the improvement of the characteristics of non-precious metal electrocatalysts. However, the control 
of the homogeneity is not easy since most of the synthesis procedures include multiple chemical steps. Especially when a precursor that includes an inbuilt homogeneous source of heteroatoms is adopted, the synthesis of a homogeneous doped carbon matrix is easier and more successful [70-72].

In Table 3, the electrochemical ORR activities in terms of half-wave potential (vs. RHE) for this class of electrocatalysts is reported. Among them, Prussian-blue, polyaniline (PANI), soya plant and others, have been investigated as alternative-raw precursors in order to facilitate the preparation procedure of electrocatalysts as well as to include a ready 3D-structure framework into the carbon matrix. These precursors contain M-N ready bonds responsible for the electrocatalysts activity enhancement [73].

Table 3. Non-precious alternative precursors' ORR electrocatalysts.

\begin{tabular}{|c|c|c|c|}
\hline Catalyst & Preparation Method and Experimental Conditions & $\begin{array}{l}\text { Limiting Current }\left(J_{\mathrm{d}} ; \mathrm{d}=\text { disc }\right) \text {, } \\
\text { Kinetic Current Density }\left(J_{\mathrm{k}}\right) \\
\text { Half Wave Potential }\left(E_{1 / 2}\right)\end{array}$ & Reference \\
\hline $\begin{array}{l}\text { C-2PANI } \\
\text { (polyaniline)/PBA } \\
\text { (prussian blue analogue), } \\
\text { 2-aniline/(aniline + PBA) }\end{array}$ & $\begin{array}{l}\text { Mixing and pyrolysis \& } 0.1 \mathrm{M} \mathrm{KOH} \text {, oxygen saturated, } \\
10 \mathrm{mV} \cdot \mathrm{s}^{-1}, 1600 \mathrm{rpm}\end{array}$ & $\begin{array}{l}J_{\mathrm{d}}=6.1 \mathrm{~mA} \cdot \mathrm{cm}^{-2} \\
E_{1 / 2}=0.85 \mathrm{~V} \text { vs. RHE }\end{array}$ & [73] \\
\hline $\begin{array}{l}\text { AFC- } 600 \text { (ammonium } \\
\text { ferric citrate, } 600: \\
\text { treatment temperature) }\end{array}$ & $\begin{array}{l}\text { A single-source molecular precursor containing } \\
\text { carbon, nitrogen and transition metal \& } 1.0 \mathrm{M} \mathrm{NaOH} \text {, } \\
\text { oxygen saturated, } 10 \mathrm{mV} \cdot \mathrm{s}^{-1}, 2500 \mathrm{rpm}\end{array}$ & $\begin{array}{l}J_{\mathrm{d}}=2.6 \mathrm{~mA} \cdot \mathrm{cm}^{-2} \\
E_{1 / 2}=0.881 \mathrm{~V} \text { vs. RHE }\end{array}$ & [74] \\
\hline $\mathrm{N}($ okara source) $-\mathrm{C}-800$ & $\begin{array}{l}\text { Nitrogen-doped carbon by okara treatment using also } \\
\mathrm{FeCl}_{3} \& 0.1 \mathrm{M} \mathrm{KOH} \text {, oxygen saturated, } 5 \mathrm{mV} \cdot \mathrm{s}^{-1} \\
1600 \mathrm{rpm}\end{array}$ & $\begin{array}{l}J_{\mathrm{d}}=4.0 \mathrm{~mA} \cdot \mathrm{cm}^{-2} \\
E_{1 / 2}=0.86 \mathrm{~V} \text { vs. RHE }\end{array}$ & [75] \\
\hline $\begin{array}{l}\text { Fe/N-gCB (co-doped } \\
\text { graphitic carbon bulb) }\end{array}$ & $\begin{array}{l}\text { Prussian blue }(\mathrm{PB}) \text { as the only precursor \& } 0.1 \mathrm{M} \mathrm{KOH} \text {, } \\
\text { oxygen saturated, } 10 \mathrm{mV} \cdot \mathrm{s}^{-1}, 1600 \mathrm{rpm}\end{array}$ & $\begin{array}{l}J_{\mathrm{d}}=5.0 \mathrm{~mA} \cdot \mathrm{cm}^{-2} \\
E_{1 / 2}=0.81 \mathrm{~V} \text { vs. RHE }\end{array}$ & [76] \\
\hline FePhen@MOF-ArNH 3 & $\begin{array}{l}\text { Encapsulation synthesis and heat treatment in } \\
\text { ammonia \& } 0.1 \mathrm{M} \mathrm{KOH} \text {, oxygen saturated, } 20 \mathrm{mV} \cdot \mathrm{s}^{-1} \text {, } \\
1600 \mathrm{rpm}\end{array}$ & $\begin{array}{l}J_{\mathrm{d}}=5.6 \mathrm{~mA} \cdot \mathrm{cm}^{-2} \\
E_{1 / 2}=0.86 \mathrm{~V} \text { vs. RHE }\end{array}$ & [77] \\
\hline $\begin{array}{l}\text { S-P-N-doped graphitized } \\
\text { carbon-1000 }\end{array}$ & $\begin{array}{l}\text { Soya (plant) as carbon source-graphitized product as } \\
\text { support \& } 0.1 \mathrm{M} \mathrm{KOH} \text {, oxygen saturated, } 5 \mathrm{mV} \cdot \mathrm{s}^{-1} \text {, } \\
1600 \mathrm{rpm}(0.1 \mathrm{M} \mathrm{KOH}+1.25 \mathrm{M} \mathrm{MeOH})\end{array}$ & $\begin{array}{l}J_{\mathrm{d}}=3.7 \mathrm{~mA} \cdot \mathrm{cm}^{-2} \\
(\mathrm{MeOH} \text { tolerant}) \\
E_{1 / 2}=0.79 \mathrm{~V} \text { vs. RHE }\end{array}$ & [78] \\
\hline $\begin{array}{l}\text { YS-Co/N-PCMs } \\
\text { (yolk-shell/porous } \\
\text { carbon microspheres) }\end{array}$ & $\begin{array}{l}\text { Template-free hydrothermal method and a subsequent } \\
\text { pyrolysis \& } 0.1 \mathrm{M} \mathrm{KOH} \text {, oxygen saturated, } 10 \mathrm{mV} \cdot \mathrm{s}^{-1} \text {, } \\
1600 \mathrm{rpm}\end{array}$ & $\begin{array}{l}J_{\mathrm{d}}=5.0 \mathrm{~mA} \cdot \mathrm{cm}^{-2} \\
E_{1 / 2}=0.706 \mathrm{~V} \mathrm{vs} . R H E \\
J_{\mathrm{k}}=16.0 \mathrm{~mA} \cdot \mathrm{cm}^{-2} \text { at } 0.3 \mathrm{~V} \text { vs. SCE }\end{array}$ & [79] \\
\hline N-S-co-doped-graphite & $\begin{array}{l}\text { Pyrolysis of homogeneous mixture of exfoliated } \\
\text { graphitic flakes and ionic liquid 1-butyl-3- } \\
\text { methylimidazoliumbis(trifluoromethanesulfonyl) } \\
\text { imide \& } 0.1 \mathrm{M} \mathrm{KOH} \text {, oxygen saturated, } 10 \mathrm{mV} \cdot \mathrm{s}^{-1} \text {, } \\
2500 \mathrm{rpm}\end{array}$ & $\begin{array}{l}J_{\mathrm{d}}=6.5 \mathrm{~mA} \cdot \mathrm{cm}^{-2} \\
E_{1 / 2}=0.768 \mathrm{~V} \text { vs. RHE }\end{array}$ & {$[80]$} \\
\hline
\end{tabular}

According to the literature review, the composition of single-source molecular precursor affects the properties of any adopted metal and carbon and consequently the ORR electrocatalyst's activity. For example, $\mathrm{Fe} / \mathrm{Fe}_{3} \mathrm{C}$ NPs encapsulated in nitrogen-doped carbon using ammonium ferritic citrate as single molecular precursor exhibited the highest according to half-wave potential, $E_{1 / 2}=0.881 \mathrm{~V}$ vs. RHE (Figure 5), ORR activity as well as an excellent methanol tolerance [74]. The conversion of amorphous carbon to graphitic carbon and the encapsulation of the iron nanoparticles into carbon's matrix were the main factors of its high ORR performance.

Another biomass product, okara, has been used as an alternative precursor, namely as nitrogen source. Okara is a byproduct from tofu and soy milk production, commonly used as feed for livestock or as a natural nitrogen fertilizer. The okara-derived nitrogen-doped carbon electrocatalyst exhibited the second highest activity, among the investigated samples, showing $0.86 \mathrm{~V}$ vs. RHE half-wave potential. This electrocatalyst was characterized by the high content of $\mathrm{sp}^{2} \mathrm{C}$, pyridinic- $\mathrm{N}$ and graphitic- $\mathrm{N}$ [75]. However, it is noted that such okara-derived catalysts are not easy to be reproduced as the composition of biomass varies considerably in reality, depending also on the factories and on the kind of soy beans.

Prussian blue is another precursor with ordered three-dimensional framework, which is consisted of coordinative bonded transition metal cations and cyanide groups. Such precursors contain M-N bonds and they are more active for ORR [76,77]. The observed high ORR activity $0.85 \mathrm{~V}$ vs. RHE is mainly attributed to the coordination of metal structure $\mathrm{MN}_{x}$ [73]. Fe/ $\mathrm{N}$ co-doped graphitic carbon 
bulb electrocatalyst was prepared using only Prussian blue as precursor; exhibiting $0.81 \mathrm{~V}$ vs. RHE half-wave potential [76].

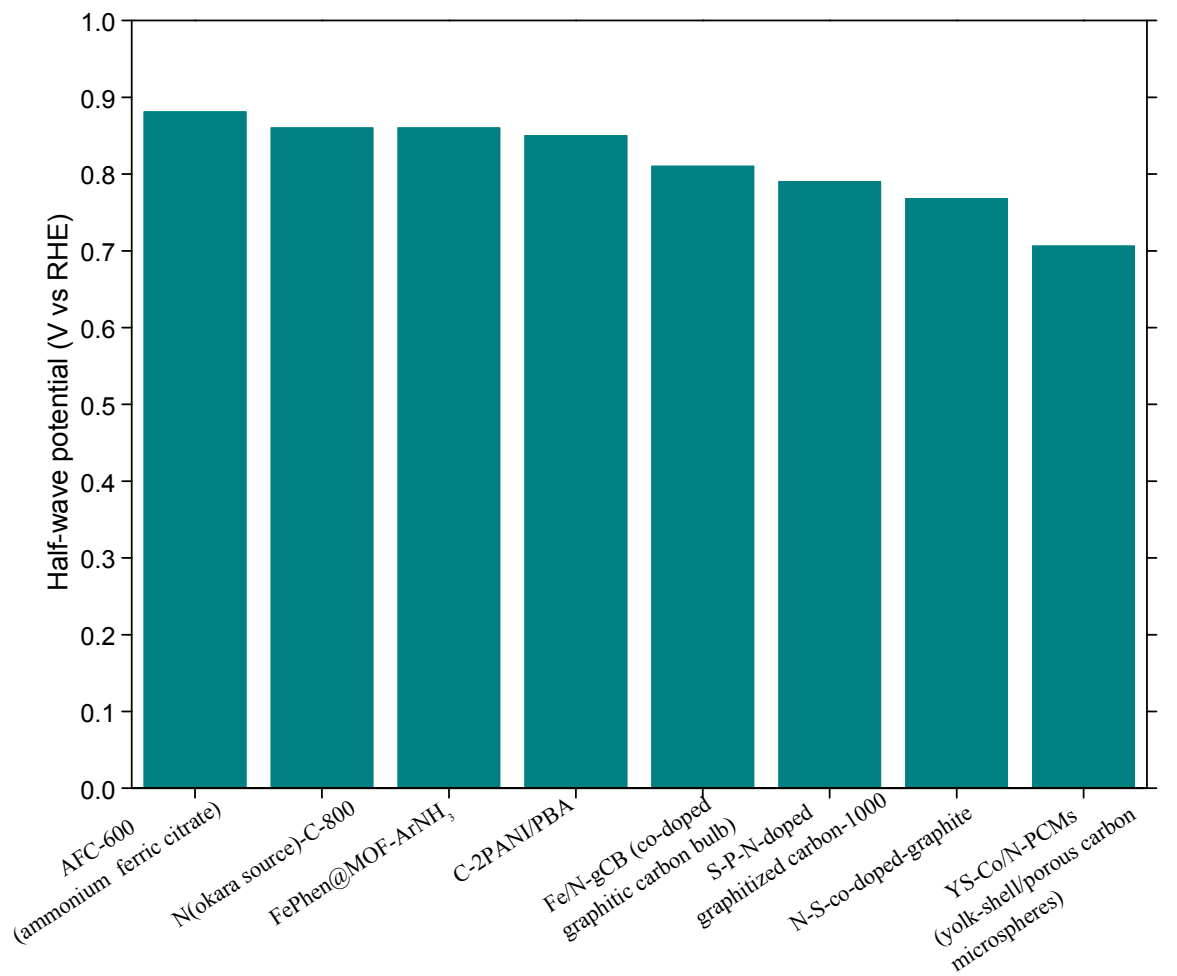

Figure 5. Comparison of half-wave potential of modified-alternative raw electrocatalytic materials. (Ref. from left to right bar: [74], [75], [77], [73], [76], [78], [80], [79]).

On the other hand, it has been also reported [77] a high ORR activity (Figure 5) for FePhen@MOF (metallic organic framework)- $\mathrm{ArNH}_{3}$ electrocatalyst, with $0.86 \mathrm{~V}$ vs. RHE half-wave potential, without observing any direct coordination of iron with nitrogen. Its high activity was attributed also to the encapsulation of Fe into N-doped carbon's matrix and its synergetic effect with nitrogen via stabilizing the peroxide intermediate. Another kind of alternative-precursor, soya plant, which is rich in proteins, can lead to multiheteroatom-doped (S-N-P) carbon electrocatalysts after the appropriate treatment [78]. More precisely, the as prepared electrocatalyst exhibited $0.79 \mathrm{~V}$ vs. RHE half-wave potential for ORR and was inactive in presence of $1.25 \mathrm{M}$ methanol. Additionally, at $0.4 \mathrm{~V}$ vs. RHE, its current density remained stable for almost one hour, while the corresponding commercial $\mathrm{Pt} / \mathrm{C}^{\prime} \mathrm{s}$ current density reduced more than $10 \%$.

By pyrolyzing a homogeneous mixture of exfoliated graphitic flakes and ionic liquid, a very active ORR electrocatalyst was fabricated performing $0.768 \mathrm{~V}$ vs. RHE [80]. The great ORR activity was ascribed to the exfoliated graphite flakes which aid to the increased nitrogen doping and consequently the increased active surface area as well as to the co-doping of nitrogen and sulfur.

Hierarchically porous carbon materials are appropriate for accommodating more active sites and are synthesized via chemically complicated routes. A template-free and easier preparation method via using melamine, formaldehyde and cobalt acetate in combination with pyrolysis were adopted to prepare hierarchically structured yolk-shell Co and $\mathrm{N}$ co-doped porous carbon microspheres by Chao et al. [79]. This structure combined the high surface of the micropores, the active sites of Co- $\mathrm{N}_{x}$ and graphitic $\mathrm{N}$, yielding $0.706 \mathrm{~V}$ vs. RHE. 


\section{Dual Hetero-Atom Doped Electrocatalysts}

Doping nitrogen can facilitate $4 \mathrm{e}^{-}$ORR process leading to water formation, while boron, sulfur, and phosphorus are more prone to enhance $2 \mathrm{e}^{-}$ORR process leading to hydrogen peroxide formation Besides, nitrogen-doped carbon materials are cheaper and also offer long durability; for this reason, in the last 2-3 years, they have been studied more intensively. Among the investigated N-doped carbon materials ordered mesoporous carbon (OMC) attracts much more attention due to the unique regular arrays of uniform mesopores [81-83].

Sheng et al. [84] recently reported a highly active N-OMC electrocatalyst which exhibited $0.853 \mathrm{~V}$ vs. RHE half-wave potential (Figure 6). Furthermore, it presented very good stability, as after $5 \mathrm{~h}$ operation at $-0.4 \mathrm{~V}$ vs. $\mathrm{Ag} / \mathrm{AgCl}$, its relative current density decreased only by $10 \%$ (Figure 7 ). The well-defined ordered mesoporous framework consisting of interconnected $\mathrm{N}$-doped carbon rods with uniform size was the reason for the high ORR activity.

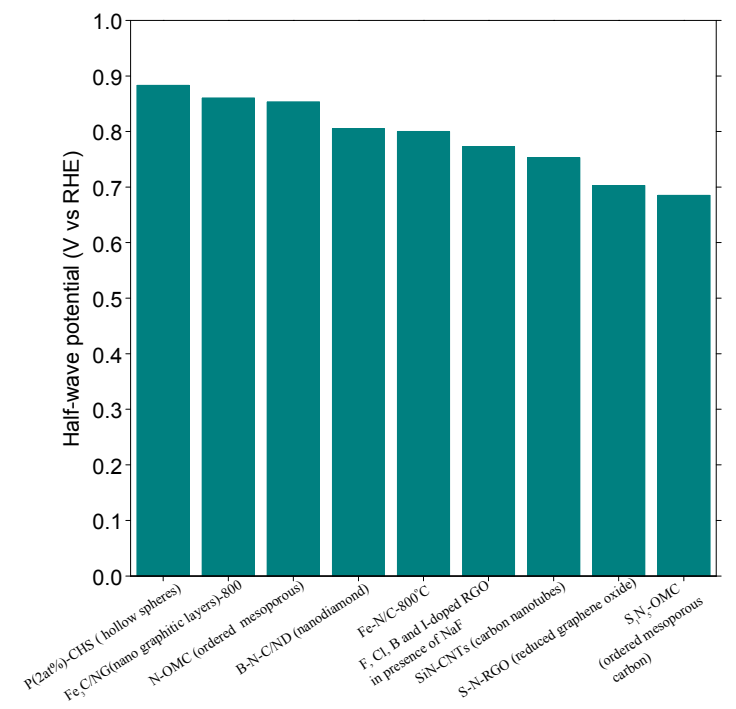

Figure 6. Comparison of ORR activity in terms of half-wave potential. (Ref. from left to right bars: [85], [86], [84], [87], [88], [89], [90], [91], [92]).

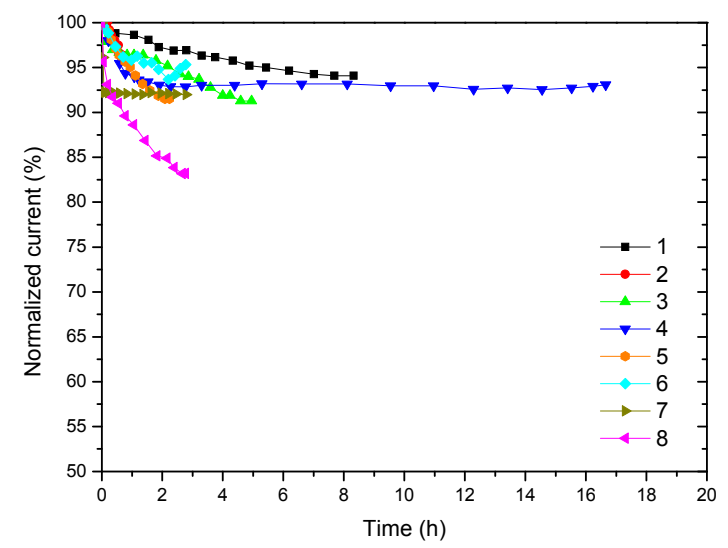

Figure 7. Long-term stability curves for modified with alternative precursor and mono or dual-doped electrocatalysts: (1) NCNT-900 (N-doped carbon nanotubes) (at -0.4 V vs. SCE) [40]; (2) S-P-N-doped graphitized carbon-1000 (at $-0.3 \mathrm{~V}$ vs. SCE) [78]; (3) NOMC (N-doped ordered mesoporous) (at $-0.3 \mathrm{~V}$ vs. $\mathrm{Ag} / \mathrm{AgCl}$ ) [84]; (4) P(2 at. \%)-CHS (phosphorus-doped hollow spheres) (at $0.8 \mathrm{~V}$ vs. RHE) [85]; (5) shell core structural boron and nitrogen co-doped graphitic carbon/nanodiamond (BN-C/ND) [87]; (6) $\mathrm{Fe}-\mathrm{N} / \mathrm{C}-800$ (at $-0.3 \mathrm{~V}$ vs. $\mathrm{Ag} / \mathrm{AgCl}$ ) [88]; (7) SiN-CNTs (at $-0.3 \mathrm{~V}$ vs. Ag/AgCl) [90]; and (8) S-doped/CNTs-900 (at $-0.3 \mathrm{~V}$ vs. $\mathrm{Ag} / \mathrm{AgCl}$ ) [93]. 
The doping of $\mathrm{N}$-doped-carbon materials with a second element such as silicon, boron, phosphorus, etc. favors the synergetic effect between the second element and the $\mathrm{N}$-doped carbon. The resulting materials exhibit a better ORR activity than single N-doped carbon materials.

For instance, phosphorus has lower electronegativity than nitrogen and sulfur, leading to a higher modification extent of carbon and having as a result a more efficient electrocatalyst towards ORR. Wu et al. [85] prepared phosphorus-doped carbon hollow spheres ( $\mathrm{P}(2$ at.\%)-CHS) electrocatalysts, which exhibited more positive than Pt's half-wave potential, $0.883 \mathrm{~V}$ vs. RHE (Figure 6). Its special structural design offered higher triple phase (solid-liquid-gas) area and consequently enhanced ORR activity. Moreover, the as-prepared electrocatalyst operating at $-0.25 \mathrm{~V}$ for almost $17 \mathrm{~h}$ lost only $5 \%$ of its initial activity (Figure 7). On the contrary, under the same operation conditions, the activity loss on $\mathrm{Pt} / \mathrm{C}$ recorded almost $20 \%$.

Iron encapsulation into carbon's matrix, as preparation method of ORR electrocatalysts' fabrication, has been adopted from other research groups too [74,78,86]. According them, the observed enhanced ORR activity was attributed to the iron's encapsulation, which stabilized the produced peroxide intermediate, and to the coordination of iron with nitrogen.

Niu et al. [88] tried to enlarge the active surface area of $\mathrm{N}$-doped mesoporous carbon by embedding rigid templates within precursor matrices. They fabricated $\mathrm{Fe}-\mathrm{N} / \mathrm{C}$ catalysts by the aid of controlled pyrolysis of a poly(2-fluoroaniline) $\left(\mathrm{P}_{2}\right.$ FANI) matrix, within which FeO- $(\mathrm{OH})$ nanorods were homogeneously embedded. They obtained a half-wave potential value of $0.8 \mathrm{~V}$ vs. RHE, the same with Pt's one. The Fe-N/C pyrolysed at $800{ }^{\circ} \mathrm{C}$ exhibited, additionally, remarkable long-term stability keeping $93.3 \%$ of its initial activity for $2.8 \mathrm{~h}$; while under the same experimental conditions $\mathrm{Pt} / \mathrm{C}$ lost half of its initial activity.

It is worth to be noticed that it is surprising that in some cases $\mathrm{Pt} / \mathrm{C}$ is so much unstable compared to non-noble metal catalysts. Part of this difference (sometimes higher than $20 \%$ ) could be due to the comparison of "normalized current" at different potentials. However, we could conclude here that most of the examined non-noble catalysts exhibit at least similar stability with $\mathrm{Pt} / \mathrm{C}$ one.

Iron has been also investigated as a second co-doped with nitrogen element. A novel nitrogen-doped-graphene nanoplatelets of $\mathrm{Fe} @ \mathrm{~N}$-graphene nanoplatelet-embedded carbon nanofibers was proposed by Ju et al. [94], delivering half-wave potential value $0.8 \mathrm{~V}$ vs. RHE (Figure 6), which is the same as Pt. Its high activity was due to the high number of functional groups.

Sulfur constitutes another element that has been investigated a lot as a second element in N-doped electrocatalysts. According to Figure 6, sulfur-nitrogen-doped CNTs [92] and sulfur-nitrogen-doped reduced graphene oxide [91] electrocatalysts exhibited 0.685 and $0.703 \mathrm{~V}$ vs. RHE half-wave potential, respectively. According to the authors of both works, the synergetic effect between $\mathrm{N}$ and $\mathrm{S}$ favors the $4 \mathrm{e}^{-}$ORR pathway. Additionally, S-N-CNTs electrocatalyst exhibited excellent methanol tolerance $(10 \mathrm{wt} \%)$ even after $2.5 \mathrm{~h}$ operation at $-0.3 \mathrm{~V}$ vs. $\mathrm{Hg} / \mathrm{HgO}$ [93]. The advantages of the ordered mesoporous structure and of the co-doping method were exploited by Jiang et al. [92], fabricating a S-N-ordered mesoporous electrocatalyst. The authors also stated very good long-term stability, as the electrocatalyst maintained $91.6 \%$ of its relative current density after $2.5 \mathrm{~h}$ operation, while $\mathrm{Pt} / \mathrm{C}$ maintained only $70 \%$ of its owns; excellent methanol $(1.0 \mathrm{M})$ tolerance was recorded.

Additionally, silicon doped into nitrogen-doped carbon nanotubes (SiN-CNTs) matrix exhibited a very good activity, $E_{1 / 2}=0.753 \mathrm{~V}$ vs. RHE (Figure 6), remaining also inactive in presence of $1.0 \mathrm{M}$ methanol. Moreover, for the first operational seconds its initial relative current decayed by $8 \%$ and it remained stable for $2.8 \mathrm{~h}$, at $-0.3 \mathrm{~V}$ vs. $\mathrm{Ag} / \mathrm{AgCl}$, while over $\mathrm{Pt} / \mathrm{C}$, the measured current decay was $30 \%[90]$.

Boron and nitrogen co-doping mostly on graphene and carbon nanotubes has been investigated thoroughly in international literature [95-98]. Liu et al. [87], recently proved that synergetic effect of co-doping and doping one by one element was the main factor for enhancing ORR activity. As depicted in Figure 6, the B-N co-doped over core shell graphitic carbon nanodiamonds electrocatalysts exhibited high half-wave potential, $E_{1 / 2}=0.805 \mathrm{~V}$ vs. RHE [87]. 
Finally, some research groups turned their attention to halogen doped-nitrogen carbon materials. By introducing a halogen element into graphene structure, its electronic structure changes, accommodating more active sites [89]. F-, $\mathrm{Cl}-, \mathrm{Br}-$ and I-co-doped reduced graphene oxide electrocatalyst, according to LSV measurements, exhibited a half-wave potential of $0.773 \mathrm{~V}$ vs. RHE; just a little more negative from Pt's. After $2000 \mathrm{~s}$, its current density remained the same, while for Pt/C it was decreased by $10 \%$.

Taking into consideration the results listed in Table 4, a common characteristic of the dual-doped electrocatalysts is the hollow carbon nanospheres, as well as the mesoporous structure. According to Figure 7, the highest long-term stability was displayed by phosphorus-doped hollow sphere electrocatalyst, ca $18 \mathrm{~h}$, maintaining $90 \%$ of its initial activity [85]. It has been stated that the hollow structure offers efficient mass transfer of the reactants. Finally, the development of ORR electrocatalysts with alternative precursors, by the aid of simpler preparation methods, is still of great challenge as deduced during the current review.

Table 4. Non-precious dual-doped carbon ORR electrocatalysts.

\begin{tabular}{|c|c|c|c|}
\hline Catalyst & Preparation Method and Experimental Conditions & $\begin{array}{l}\text { Limiting Current }\left(J_{d} ; d=\text { disc }\right) \text {, } \\
\text { Kinetic Current Density }\left(J_{k}\right) \text {, } \\
\left.\text { Half-Wave Potential }\left(E_{1 / 2}\right)\right)\end{array}$ & Reference \\
\hline $\begin{array}{l}\mathrm{N}-\mathrm{OMC}(\mathrm{N} \text {-doped ordered } \\
\text { mesoporous) }\end{array}$ & $\begin{array}{l}\text { Two-step nanocasting method (DHN as precursors) \& } \\
0.1 \mathrm{M} \mathrm{KOH} \text {, oxygen saturated } 10 \mathrm{mV} \cdot \mathrm{s}^{-1}, 2500 \mathrm{rpm}\end{array}$ & $\begin{array}{l}J_{\mathrm{d}}=5.8 \mathrm{~mA} \cdot \mathrm{cm}^{-2} \\
J_{\mathrm{k}}=22 \mathrm{~mA} \cdot \mathrm{cm}^{-2}(\text { at } 0.4 \mathrm{~V} \text { vs. } \\
\mathrm{Ag} / \mathrm{AgCl}) \\
E_{1 / 2}=0.853 \mathrm{~V} \text { vs. RHE }\end{array}$ & [84] \\
\hline $\begin{array}{l}\mathrm{P}(2 \text { at. \%)-CHS } \\
\text { (phosphorus-doped } \\
\text { hollow spheres) }\end{array}$ & $\begin{array}{l}\text { Hydrothermal method using glucose as a carbon } \\
\text { source, tetraphenylphosphonium bromide as a P } \\
\text { source and anionic surfactant sodium dodecyl sulfate } \\
\text { as a soft template \& } 0.1 \mathrm{M} \mathrm{KOH,} \mathrm{oxygen} \mathrm{saturated} \\
10 \mathrm{mV} \cdot \mathrm{s}^{-1}, 1600 \mathrm{rpm}\end{array}$ & $\begin{array}{l}J_{\mathrm{d}}=5.7 \mathrm{~mA} \cdot \mathrm{cm}^{-2} \\
E_{1 / 2}=0.883 \mathrm{~V} \text { vs. RHE }\end{array}$ & [85] \\
\hline $\begin{array}{l}\mathrm{Fe}_{3} \mathrm{C} / \mathrm{N}-\mathrm{G}(\text { nano graphitic } \\
\text { layers)-800 }\end{array}$ & $\begin{array}{l}\text { Pyrolysis of poly (1,8-diaminonapphthalene) (PDAN) } \\
\text { using precursors of 1,8-diaminonaphthalene (DAN) } \\
\text { and } \mathrm{FeCl}_{3} \& 0.1 \mathrm{M} \mathrm{KOH} \text {, oxygen saturated, } 5 \mathrm{mV} \cdot \mathrm{s}^{-1} \text {, } \\
1600 \mathrm{rpm},(0.1 \mathrm{M} \mathrm{KOH}+1.0 \mathrm{M} \mathrm{MeOH})\end{array}$ & $\begin{array}{l}J_{\mathrm{d}}=5.8 \mathrm{~mA} \cdot \mathrm{cm}^{-2} \\
E_{1 / 2}=0.86 \mathrm{~V} \text { vs. RHE } \\
\text { (Inactive in MeOH presence) }\end{array}$ & [86] \\
\hline $\begin{array}{l}\text { Shell core structural } \mathrm{B} \text { and } \mathrm{N} \\
\text { co-doped graphitic } \\
\text { carbon/nanodiamond } \\
\text { (BN-C/ND) }\end{array}$ & $\begin{array}{l}\text { One-step heat-treatment of the mixture with } \\
\text { nanodiamond, melamine, boric acid and } \mathrm{FeCl}_{3} \\
\& 0.1 \mathrm{M} \mathrm{KOH} \text {, oxygen saturated, } 10 \mathrm{mV} \cdot \mathrm{s}^{-1}, 1600 \mathrm{rpm} \\
(0.1 \mathrm{M} \mathrm{KOH}+1.0 \mathrm{M} \mathrm{MeOH})\end{array}$ & $\begin{array}{l}J_{\mathrm{d}}=6.0 \mathrm{~mA} \cdot \mathrm{cm}^{-2} \\
E_{1 / 2}=0.22 \mathrm{~V} \text { vs. } \mathrm{Hg} / \mathrm{HgO}(0.805 \mathrm{~V} \\
\text { vs. RHE) } \\
\text { (Inactive in } \mathrm{MeOH} \text { presence) }\end{array}$ & [87] \\
\hline $\mathrm{Fe}-\mathrm{N} / \mathrm{C}-800$ & $\begin{array}{l}\text { Thermally removable nanoparticle templates \& } \\
0.1 \mathrm{M} \mathrm{KOH} \text {, oxygen saturated }(0.1 \mathrm{M} \mathrm{KOH}+ \\
1.0 \mathrm{M} \mathrm{MeOH})\end{array}$ & $\begin{array}{l}J_{\mathrm{d}}=4.9 \mathrm{~mA} \cdot \mathrm{cm}^{-2} \\
E_{1 / 2}=0.80 \mathrm{~V} \text { vs. RHE } \\
\text { (Inactive in MeOH presence) }\end{array}$ & [88] \\
\hline $\begin{array}{l}\mathrm{F}, \mathrm{Cl}, \mathrm{B} \text { and } \mathrm{I}-\text { doped } \mathrm{RGO} \text { in } \\
\text { presence of } \mathrm{NaF}\end{array}$ & $\begin{array}{l}\text { Halogenations of reduced graphene oxide (RGO) with } \\
\text { simultaneously fluorine, chlorine, bromine and iodine } \\
\text { by electrochemical exfoliation of } \mathrm{GO} \text { and obtained } \\
\text { XRGO in presence of IL and halogen salts }(\mathrm{X}=\mathrm{F}, \mathrm{Cl} \text {, } \\
\mathrm{Br} \text {, I) \& } 0.5 \mathrm{M} \mathrm{KOH} \text {, oxygen saturated, } 10 \mathrm{mV} \cdot \mathrm{s}^{-1} \text {, } \\
1600 \mathrm{rpm}\end{array}$ & $\begin{array}{l}J_{\mathrm{d}}=5.7 \mathrm{~mA} \cdot \mathrm{cm}^{-2} \\
E_{1 / 2}=0.773 \mathrm{~V} \text { vs. RHE }\end{array}$ & [89] \\
\hline SiN-CNTs & $\begin{array}{l}\text { Thermolysis of 3-aminopropyl-triethoxysilane and } \\
\text { dimethylsilicone oil, respectively, using FeMo/ } \mathrm{Al}_{2} \mathrm{O}_{3} \\
\text { as catalysts \& } 0.1 \mathrm{M} \mathrm{KOH} \text {, oxygen saturated } 5 \mathrm{mV} \cdot \mathrm{s}^{-1} \text {, } \\
1600 \mathrm{rpm}(0.1 \mathrm{M} \mathrm{KOH}+1.0 \mathrm{M} \mathrm{MeOH})\end{array}$ & $\begin{array}{l}J_{\mathrm{d}}=6.12 \mathrm{~mA} \cdot \mathrm{cm}^{-2} \\
E_{1 / 2}=0.753 \mathrm{~V} \text { vs. RHE } \\
\text { (Inactive in MeOH presence) }\end{array}$ & [90] \\
\hline $\begin{array}{l}\text { S-N-RGO (reduced } \\
\text { graphene oxide) }\end{array}$ & $\begin{array}{l}\text { Single-step non-hydrothermal chemical route Reflux in } \\
\text { ethylene glycol at } 180^{\circ} \mathrm{C} \text { for } 3 \mathrm{~h} \& 0.1 \mathrm{M} \mathrm{KOH} \text {, } \\
\text { oxygen saturated, } 5 \mathrm{mV} \cdot \mathrm{s}^{-1}, 1600 \mathrm{rpm}\end{array}$ & $\begin{array}{l}J_{\mathrm{d}}=5.1 \mathrm{~mA} \cdot \mathrm{cm}^{-2} \\
E_{1 / 2}=0.703 \mathrm{~V} \text { vs. RHE } \\
J_{\mathrm{k}}=7.7 \mathrm{~mA} \cdot \mathrm{cm}^{-2}(\text { at } 0.6 \mathrm{~V} \text { vs. } \\
\mathrm{Hg} / \mathrm{HgO})\end{array}$ & [91] \\
\hline $\begin{array}{l}\mathrm{S}_{1} \mathrm{~N}_{5}-\mathrm{OMC} \text { (dual doped } \\
\text { with } \mathrm{S} \text { and } \mathrm{N} \text { ordered } \\
\text { mesoporous carbon) }\end{array}$ & $\begin{array}{l}\text { Polythiophene (PTh) and polypyrrole (PPy) as the } \\
\text { precursors, ordered mesoporous silica (SBA-15) as the } \\
\text { hard template, and } \mathrm{FeCl}_{3} \text { as the catalyst \& } 0.1 \mathrm{M} \mathrm{KOH} \text {, } \\
\text { oxygen saturated, } 10 \mathrm{mV} \cdot \mathrm{s}^{-1}, 1600 \mathrm{rpm},(0.1 \mathrm{M} \mathrm{KOH}+ \\
0.5 \mathrm{M} \mathrm{MeOH})\end{array}$ & $\begin{array}{l}J_{\mathrm{d}}=4.6 \mathrm{~mA} \cdot \mathrm{cm}^{-2} \\
E_{1 / 2}=0.685 \mathrm{~V} \text { vs. RHE } \\
\text { (Inactive in MeOH presence) }\end{array}$ & [92] \\
\hline
\end{tabular}

\section{Conclusions}

The present review mainly focuses on novel carbon based materials for ORR, including: (i) the development of three-dimensional structures; (ii) the synthesis of novel hybrid (metal oxide-nitrogen-carbon) electrocatalysts; (iii) the use of alternative raw precursors 
characterized from three-dimensional structure; (iv) the adoption of co-doping methods for novel metal-nitrogen-doped-carbon electrocatalysts.

Hybrid-materials exceed the other types of electrocatalysts in terms of ORR activity as well as long-term stability. Among them, nitrogen-doped-reduced graphene oxide with mesoporous structure is the most efficient support. However, the greatest challenge of those electrocatalysts is the simplification of their synthesis procedure. Towards this direction, non-precious ORR electrocatalysts via one step process utilizing alternative precursors, mainly Prussian-blue and/or polyaniline, were prepared. The main advantage of these kinds of alternative precursors is their ready (from their nature) three-dimensional structures offering enriched $\mathrm{M}-\mathrm{N}$ bonds, which, after pyrolysis, form $\mathrm{MN}_{x}$ ORR active sites. The same precursors can serve also as carbon or nitrogen sources. This class of electrocatalysts exhibits very good ORR electrochemical activity; however, their main drawback is their short stability over time.

In their turn, dual-doped ORR electrocatalysts succeed to change the ORR mechanism in N-doped electrocatalysts from $2 \mathrm{e}^{-}$to $4 \mathrm{e}^{-}$process. The most efficient dual-doped electrocatalysts: (i) are characterized by either ordered mesoporous or hollow mesoporous graphene structure; (ii) have been prepared by co-doping metals; and (iii) the doped-metals have been embedded throughout carbon matrix and not at its edges. In terms of long-term stability, it can be deduced that they are less stable than hybrids, but more stable than the alternative precursors' electrocatalysts.

Finally, $3 D$ interconnected structures facilitate electron and mass transfer. The key for the development of the most active electrocatalyst (3D Co-N-OMMC) was the combination of: (i) co-doping of the two metals; (ii) highly ordered macro-mesoporous graphene's structure; and (iii) synergetic effect of the two metals with the support. Typically, their ORR activity is still lower than the other as-reported electrocatalysts. The degradation of their structure and, consequently, the much lower stability are the main challenges that need to be overcome in future.

Acknowledgments: The authors are grateful to the Sino-Greek Science and Technology Cooperation (Project 2013DFG62590), the National Natural Science Foundation of China (Grant No. 21575299, 21576300, and 21276290), and to the Guangdong Province Nature Science Foundation (2014A030313150) for the financial support. Panagiotis Tsiakaras is also grateful to the Ministry of Education and Science of the Russian Federation (Mega-grant contract No. 14.Z50.31.0001) for funding.

Author Contributions: Angeliki Brouzgou searched the literature papers, categorized the electrocatalysts in the present paper and wrote the main part of the current work; Shuqin Song and Zhen-Xing Liang corrected English, helped with data analysis and wrote part of this work; Panagiotis Tsiakaras wrote part of this work, corrected English grammar and syntax and supervised the whole work.

Conflicts of Interest: The authors declare no conflict of interest.

\section{References}

1. Brouzgou, A.; Song, S.Q.; Tsiakaras, P. Low and non-platinum electrocatalysts for pemfcs: Current status, challenges and prospects. Appl. Catal. B Environ. 2012, 127, 371-388. [CrossRef]

2. Wang, Y.; He, C.; Brouzgou, A.; Liang, Y.; Fu, R.; Wu, D.; Tsiakaras, P.; Song, S. A facile soft-template synthesis of ordered mesoporous carbon/tungsten carbide composites with high surface area for methanol electrooxidation. J. Power Sources 2012, 200, 8-13. [CrossRef]

3. Brouzgou, A.; Podias, A.; Tsiakaras, P. PEMFCS and AEMFCS directly fed with ethanol: A current status comparative review. J. Appl. Electrochem. 2013, 43, 119-136. [CrossRef]

4. Wan, K.; Long, G.-F.; Liu, M.-Y.; Du, L.; Liang, Z.-X.; Tsiakaras, P. Nitrogen-doped ordered mesoporous carbon: Synthesis and active sites for electrocatalysis of oxygen reduction reaction. Appl. Catal. B Environ. 2015, 165, 566-571. [CrossRef]

5. Gong, K.; Du, F.; Xia, Z.; Durstock, M.; Dai, L. Nitrogen-doped carbon nanotube arrays with high electrocatalytic activity for oxygen reduction. Science 2009, 323, 760-764. [CrossRef] [PubMed]

6. Lee, J.S.; Park, G.S.; Kim, S.T.; Liu, M.; Cho, J. A highly efficient electrocatalyst for the oxygen reduction reaction: N-doped ketjenblack incorporated into $\mathrm{Fe} / \mathrm{Fe}_{3} \mathrm{C}$-functionalized melamine foam. Angew. Chem. 2013, 125, 1060-1064. [CrossRef] 
7. Choi, C.H.; Chung, M.W.; Kwon, H.C.; Park, S.H.; Woo, S.I. B, N-and P, N-doped graphene as highly active catalysts for oxygen reduction reactions in acidic media. J. Mater. Chem. A 2013, 1, 3694-3699. [CrossRef]

8. Xue, Y.; Yu, D.; Dai, L.; Wang, R.; Li, D.; Roy, A.; Lu, F.; Chen, H.; Liu, Y.; Qu, J. Three-dimensional B, N-doped graphene foam as a metal-free catalyst for oxygen reduction reaction. Phys. Chem. Chem. Phys. 2013, 15, 12220-12226. [CrossRef] [PubMed]

9. Zhang, L.; Niu, J.; Li, M.; Xia, Z. Catalytic mechanisms of sulfur-doped graphene as efficient oxygen reduction reaction catalysts for fuel cells. J. Phys. Chem. C 2014, 118, 3545-3553. [CrossRef]

10. Park, J.-E.; Jang, Y.J.; Kim, Y.J.; Song, M.-S.; Yoon, S.; Kim, D.H.; Kim, S.-J. Sulfur-doped graphene as a potential alternative metal-free electrocatalyst and Pt-catalyst supporting material for oxygen reduction reaction. Phys. Chem. Chem. Phys. 2014, 16, 103-109. [CrossRef] [PubMed]

11. Ma, Z.; Dou, S.; Shen, A.; Tao, L.; Dai, L.; Wang, S. Sulfur-doped graphene derived from cycled lithium-sulfur batteries as a metal-free electrocatalyst for the oxygen reduction reaction. Angew. Chem. Int. Ed. 2015, 54, 1888-1892. [CrossRef] [PubMed]

12. Peng, H.; Mo, Z.; Liao, S.; Liang, H.; Yang, L.; Luo, F.; Song, H.; Zhong, Y.; Zhang, B. High performance Fe-and N-doped carbon catalyst with graphene structure for oxygen reduction. Sci. Rep. 2013. [CrossRef]

13. Liang, J.; Zhou, R.F.; Chen, X.M.; Tang, Y.H.; Qiao, S.Z. Fe-N decorated hybrids of CNTs grown on hierarchically porous carbon for high-performance oxygen reduction. Adv. Mater. 2014, 26, 6074-6079. [CrossRef] [PubMed]

14. Wu, J.; Yang, Z.; Li, X.; Sun, Q.; Jin, C.; Strasser, P.; Yang, R. Phosphorus-doped porous carbons as efficient electrocatalysts for oxygen reduction. J. Mater. Chem. A 2013, 1, 9889-9896. [CrossRef]

15. Zhang, C.; Mahmood, N.; Yin, H.; Liu, F.; Hou, Y. Synthesis of phosphorus-doped graphene and its multifunctional applications for oxygen reduction reaction and lithium ion batteries. Adv. Mater. 2013, 25, 4932-4937. [CrossRef] [PubMed]

16. Li, R.; Wei, Z.; Gou, X.; Xu, W. Phosphorus-doped graphene nanosheets as efficient metal-free oxygen reduction electrocatalysts. RSC Adv. 2013, 3, 9978-9984. [CrossRef]

17. Liang, Y.; Wang, H.; Diao, P.; Chang, W.; Hong, G.; Li, Y.; Gong, M.; Xie, L.; Zhou, J.; Wang, J.; et al. Oxygen reduction electrocatalyst based on strongly coupled cobalt oxide nanocrystals and carbon nanotubes. J. Am. Chem. Soc. 2012, 134, 15849-15857. [CrossRef] [PubMed]

18. Yang, Z.; Yao, Z.; Li, G.; Fang, G.; Nie, H.; Liu, Z.; Zhou, X.; Chen, X.; Huang, S. Sulfur-doped graphene as an efficient metal-free cathode catalyst for oxygen reduction. ACS Nano 2012, 6, 205-211. [CrossRef] [PubMed]

19. Liu, R.; Wu, D.; Feng, X.; Müllen, K. Nitrogen-doped ordered mesoporous graphitic arrays with high electrocatalytic activity for oxygen reduction. Angew. Chem. Int. Ed. 2010, 49, 2565-2569. [CrossRef] [PubMed]

20. Niwa, H.; Horiba, K.; Harada, Y.; Oshima, M.; Ikeda, T.; Terakura, K.; Ozaki, J.-I.; Miyata, S. X-ray absorption analysis of nitrogen contribution to oxygen reduction reaction in carbon alloy cathode catalysts for polymer electrolyte fuel cells. J. Power Sources 2009, 187, 93-97. [CrossRef]

21. Ferrandon, M.; Kropf, A.J.; Myers, D.J.; Artyushkova, K.; Kramm, U.; Bogdanoff, P.; Wu, G.; Johnston, C.M.; Zelenay, P. Multitechnique characterization of a polyaniline-iron-carbon oxygen reduction catalyst. J. Phys. Chem. C 2012, 116, 16001-16013. [CrossRef]

22. Wu, G.; More, K.L.; Johnston, C.M.; Zelenay, P. High-performance electrocatalysts for oxygen reduction derived from polyaniline, iron, and cobalt. Science 2011, 332, 443-447. [CrossRef] [PubMed]

23. Zhang, P.; Sun, F.; Xiang, Z.; Shen, Z.; Yun, J.; Cao, D. Zif-derived in situ nitrogen-doped porous carbons as efficient metal-free electrocatalysts for oxygen reduction reaction. Energy Environ. Sci. 2014, 7, 442-450. [CrossRef]

24. Zhang, Y.; Chu, M.; Yang, L.; Deng, W.; Tan, Y.; Ma, M.; Xie, Q. Synthesis and oxygen reduction properties of three-dimensional sulfur-doped graphene networks. Chem. Commun. 2014, 50, 6382-6385. [CrossRef] [PubMed]

25. Fang, B.; Kim, J.H.; Kim, M.-S.; Yu, J.-S. Hierarchical nanostructured carbons with meso-macroporosity: Design, characterization, and applications. Acc. Chem. Res. 2013, 46, 1397-1406. [CrossRef] [PubMed]

26. Wang, J.G.; Zhou, H.J.; Sun, P.C.; Ding, D.T.; Chen, T.H. Hollow carved single-crystal mesoporous silica templated by mesomorphous polyelectrolyte-surfactant complexes. Chem. Mater. 2010, 22, 3829-3831. [CrossRef] 
27. Liu, Y.-L.; Shi, C.-X.; Xu, X.-Y.; Sun, P.-C.; Chen, T.-H. Nitrogen-doped hierarchically porous carbon spheres as efficient metal-free electrocatalysts for an oxygen reduction reaction. J. Power Sources 2015, 283, 389-396. [CrossRef]

28. Tao, G.; Zhang, L.; Chen, L.; Cui, X.; Hua, Z.; Wang, M.; Wang, J.; Chen, Y.; Shi, J. N-doped hierarchically macro/mesoporous carbon with excellent electrocatalytic activity and durability for oxygen reduction reaction. Carbon 2015, 86, 108-117. [CrossRef]

29. Sun, T.; Xu, L.; Li, S.; Chai, W.; Huang, Y.; Yan, Y.; Chen, J. Cobalt-nitrogen-doped ordered macro-/ mesoporous carbon for highly efficient oxygen reduction reaction. Appl. Catal. B Environ. 2016, 193, 1-8. [CrossRef]

30. Duan, J.; Zheng, Y.; Chen, S.; Tang, Y.; Jaroniec, M.; Qiao, S. Mesoporous hybrid material composed of $\mathrm{Mn}_{3} \mathrm{O}_{4}$ nanoparticles on nitrogen-doped graphene for highly efficient oxygen reduction reaction. Chem. Commun. 2013, 49, 7705-7707. [CrossRef] [PubMed]

31. Hao, J.; Liu, Y.; Shen, H.; Li, W.; Li, J.; Li, Y.; Chen, Q. Effect of nickel-ion doping in $\mathrm{MnO}_{2}$ nanoneedles as electrocatalyst for the oxygen reduction reaction. J. Mater. Sci. Mater. Electron. 2016, 27, 6598-6605. [CrossRef]

32. Bian, W.; Yang, Z.; Strasser, P.; Yang, R. A CoFe $\mathrm{O}_{4}$ /graphene nanohybrid as an efficient bi-functional electrocatalyst for oxygen reduction and oxygen evolution. J. Power Sources 2014, 250, 196-203. [CrossRef]

33. Huo, R.; Jiang, W.J.; Xu, S.; Zhang, F.; Hu, J.S. Co/CoO/CoFe ${ }_{2} \mathrm{O}_{4} / \mathrm{G}$ nanocomposites derived from layered double hydroxides towards mass production of efficient $\mathrm{Pt}$-free electrocatalysts for oxygen reduction reaction. Nanoscale 2014, 6, 203-206. [CrossRef] [PubMed]

34. Xu, Y.; Bian, W.; Wu, J.; Tian, J.-H.; Yang, R. Preparation and electrocatalytic activity of 3D hierarchical porous spinel $\mathrm{CoFe}_{2} \mathrm{O}_{4}$ hollow nanospheres as efficient catalyst for oxygen reduction reaction and oxygen evolution reaction. Electrochim. Acta 2015, 151, 276-283. [CrossRef]

35. Wang, J.; Wu, Z.; Han, L.; Lin, R.; Xin, H.L.; Wang, D. Hollow-structured carbon-supported nickel cobaltite nanoparticles as an efficient bifunctional electrocatalyst for the oxygen reduction and evolution reactions. ChemCatChem 2016, 8, 736-742. [CrossRef]

36. Lee, E.; Jang, J.-H.; Kwon, Y.-U. Composition effects of spinel $\mathrm{Mn}_{x} \mathrm{Co}_{3-x} \mathrm{O}_{4}$ nanoparticles on their electrocatalytic properties in oxygen reduction reaction in alkaline media. J. Power Sources 2015, 273, 735-741. [CrossRef]

37. Ma, Y.; Wang, R.; Wang, H.; Key, J.; Ji, S. Control of $\mathrm{MnO}_{2}$ nanocrystal shape from tremella to nanobelt for ehancement of the oxygen reduction reaction activity. J. Power Sources 2015, 280, 526-532. [CrossRef]

38. Odedairo, T.; Yan, X.; Ma, J.; Jiao, Y.; Yao, X.; Du, A.; Zhu, Z. Nanosheets $\mathrm{Co}_{3} \mathrm{O}_{4}$ interleaved with graphene for highly efficient oxygen reduction. ACS Appl. Mater. Interfaces 2015, 7, 21373-21380. [CrossRef] [PubMed]

39. Li, Z.; Shao, M.; Zhou, L.; Zhang, R.; Zhang, C.; Wei, M.; Evans, D.G.; Duan, X. Directed growth of metal-organic frameworks and their derived carbon-based network for efficient electrocatalytic oxygen reduction. Adv. Mater. 2016, 28, 2337-2344. [CrossRef] [PubMed]

40. Pan, T.; Liu, H.; Ren, G.; Li, Y.; Lu, X.; Zhu, Y. Metal-free porous nitrogen-doped carbon nanotubes for enhanced oxygen reduction and evolution reactions. Sci. Bull. 2016, 61, 889-896. [CrossRef]

41. Hao, L.; Zhang, S.; Liu, R.; Ning, J.; Zhang, G.; Zhi, L. Bottom-up construction of triazine-based frameworks as metal-free electrocatalysts for oxygen reduction reaction. Adv. Mater. 2015, 27, 3190-3195. [CrossRef] [PubMed]

42. Xu, Y.; Jin, S.; Xu, H.; Nagai, A.; Jiang, D. Conjugated microporous polymers: Design, synthesis and application. Chem. Soc. Rev. 2013, 42, 8012-8031. [CrossRef] [PubMed]

43. Zhang, L.; Su, Z.; Jiang, F.; Yang, L.; Qian, J.; Zhou, Y.; Li, W.; Hong, M. Highly graphitized nitrogen-doped porous carbon nanopolyhedra derived from ZIF-8 nanocrystals as efficient electrocatalysts for oxygen reduction reactions. Nanoscale 2014, 6, 6590-6602. [CrossRef] [PubMed]

44. Miner, E.M.; Fukushima, T.; Sheberla, D.; Sun, L.; Surendranath, Y.; Dincă, M. Electrochemical oxygen reduction catalysed by $\mathrm{Ni}_{3}$ (hexaiminotriphenylene) 2 . Nat. Commun. 2016, 7, 10942. [CrossRef] [PubMed]

45. Verma, A.; Jha, A.K.; Basu, S. Manganese dioxide as a cathode catalyst for a direct alcohol or sodium borohydride fuel cell with a flowing alkaline electrolyte. J. Power Sources 2005, 141, 30-34. [CrossRef]

46. Rojas-Carbonell, S.; Babanova, S.; Serov, A.; Ulyanova, Y.; Singhal, S.; Atanassov, P. Hybrid electrocatalysts for oxygen reduction reaction: Integrating enzymatic and non-platinum group metal catalysis. Electrochim. Acta 2016, 190, 504-510. [CrossRef] 
47. Zhang, G.; Lu, W.; Cao, F.; Xiao, Z.; Zheng, X. N-doped graphene coupled with Co nanoparticles as an efficient electrocatalyst for oxygen reduction in alkaline media. J. Power Sources 2016, 302, 114-125. [CrossRef]

48. Jin, J.; Pan, F.; Jiang, L.; Fu, X.; Liang, A.; Wei, Z.; Zhang, J.; Sun, G. Catalyst-free synthesis of crumpled boron and nitrogen Co-doped graphite layers with tunable bond structure for oxygen reduction reaction. ACS Nano 2014, 8, 3313-3321. [CrossRef] [PubMed]

49. Wang, Y.; Wang, Z.; Wu, X.; Liu, X.; Li, M. Synergistic effect between strongly coupled coal layered double hydroxides and graphene for the electrocatalytic reduction of oxygen. Electrochim. Acta 2016, 192, 196-204. [CrossRef]

50. Han, J.; Sa, Y.J.; Shim, Y.; Choi, M.; Park, N.; Joo, S.H.; Park, S. Coordination chemistry of [Co(acac) $\left.{ }_{2}\right]$ with $\mathrm{N}$-doped graphene: Implications for oxygen reduction reaction reactivity of organometallic $\mathrm{Co}_{0}-\mathrm{O}_{4}-\mathrm{N}$ species. Angew. Chem. Int. Ed. 2015, 54, 12622-12626. [CrossRef] [PubMed]

51. Chao, S.; Bai, Z.; Cui, Q.; Yan, H.; Wang, K.; Yang, L. Hollowed-out octahedral Co/N-codoped carbon as a highly efficient non-precious metal catalyst for oxygen reduction reaction. Carbon 2015, 82, 77-86. [CrossRef]

52. Zhan, Y.; Du, G.; Yang, S.; Xu, C.; Lu, M.; Liu, Z.; Lee, J.Y. Development of cobalt hydroxide as a bifunctional catalyst for oxygen electrocatalysis in alkaline solution. ACS Appl. Mater. Interfaces 2015, 7, 12930-12936. [CrossRef] [PubMed]

53. Hou, Y.; Wen, Z.; Cui, S.; Ci, S.; Mao, S.; Chen, J. An advanced nitrogen-doped graphene/cobalt-embedded porous carbon oolyhedron hybrid for efficient catalysis of oxygen reduction and water splitting. Adv. Funct. Mater. 2015, 25, 872-882. [CrossRef]

54. Wu, Y.; Shi, Q.; Li, Y.; Lai, Z.; Yu, H.; Wang, H.; Peng, F. Nitrogen-doped graphene-supported cobalt carbonitride@oxide core-shell nanoparticles as a non-noble metal electrocatalyst for an oxygen reduction reaction. J. Mater. Chem. A 2015, 3, 1142-1151. [CrossRef]

55. Ge, L.; Yang, Y.; Wang, L.; Zhou, W.; De Marco, R.; Chen, Z.; Zou, J.; Zhu, Z. High activity electrocatalysts from metal-organic framework-carbon nanotube templates for the oxygen reduction reaction. Carbon 2015, 82, 417-424. [CrossRef]

56. Yang, W.; Liu, X.; Yue, X.; Jia, J.; Guo, S. Bamboo-like carbon nanotube/ $\mathrm{Fe}_{3} \mathrm{C}$ nanoparticle hybrids and their highly efficient catalysis for oxygen reduction. J. Am. Chem. Soc. 2015, 137, 1436-1439. [CrossRef] [PubMed]

57. Zhang, M.; Li, R.; Chang, X.; Xue, C.; Gou, X. Hybrid of porous cobalt oxide nanospheres and nitrogen-doped graphene for applications in lithium-ion batteries and oxygen reduction reaction. J. Power Sources 2015, 290, 25-34. [CrossRef]

58. Lv, L.-B.; Ye, T.-N.; Gong, L.-H.; Wang, K.-X.; Su, J.; Li, X.-H.; Chen, J.-S. Anchoring cobalt nanocrystals through the plane of graphene: Highly integrated electrocatalyst for oxygen reduction reaction. Chem. Mater. 2015, 27, 544-549. [CrossRef]

59. Cao, S.; Han, N.; Han, J.; Hu, Y.; Fan, L.; Zhou, C.; Guo, R. Mesoporous hybrid shells of carbonized polyaniline $/ \mathrm{Mn}_{2} \mathrm{O}_{3}$ as non-precious efficient oxygen reduction reaction catalyst. ACS Appl. Mater. Interfaces 2016, 8, 6040-6050. [CrossRef] [PubMed]

60. Huang, W.; Zhong, H.; Li, D.; Tang, P.; Feng, Y. Reduced graphene oxide supported $\mathrm{CoO} / \mathrm{MnO}_{2}$ electrocatalysts from layered double hydroxides for oxygen reduction reaction. Electrochim. Acta 2015, 173, 575-580. [CrossRef]

61. Zheng, Y.; Jiao, Y.; Ge, L.; Jaroniec, M.; Qiao, S.Z. Two-step boron and nitrogen doping in graphene for enhanced synergistic catalysis. Angew. Chem. 2013, 125, 3192-3198. [CrossRef]

62. Zhao, Y.; Yang, L.; Chen, S.; Wang, X.; Ma, Y.; Wu, Q.; Jiang, Y.; Qian, W.; Hu, Z. Can boron and nitrogen co-doping improve oxygen reduction reaction activity of carbon nanotubes? J. Am. Chem. Soc. 2013, 135, 1201-1204. [CrossRef] [PubMed]

63. Ding, W.; Wei, Z.; Chen, S.; Qi, X.; Yang, T.; Hu, J.; Wang, D.; Wan, L.J.; Alvi, S.F.; Li, L. Space-confinementinduced synthesis of pyridinic-and pyrrolic-nitrogen-doped graphene for the catalysis of oxygen reduction. Angew. Chem. 2013, 125, 11971-11975. [CrossRef]

64. Cao, Y.; Wei, Z.; He, J.; Zang, J.; Zhang, Q.; Zheng, M.; Dong, Q. $\alpha-\mathrm{MnO}_{2}$ nanorods grown in situ on graphene as catalysts for $\mathrm{Li}-\mathrm{O}_{2}$ batteries with excellent electrochemical performance. Energy Environ. Sci. 2012, 5 , 9765-9768. [CrossRef]

65. Qu, L.; Liu, Y.; Baek, J.-B.; Dai, L. Nitrogen-doped graphene as efficient metal-free electrocatalyst for oxygen reduction in fuel cells. ACS Nano 2010, 4, 1321-1326. [CrossRef] [PubMed] 
66. Lin, Z.; Waller, G.; Liu, Y.; Liu, M.; Wong, C.P. Facile synthesis of nitrogen-doped graphene via pyrolysis of graphene oxide and urea, and its electrocatalytic activity toward the oxygen-reduction reaction. Adv. Energy Mater. 2012, 2, 884-888. [CrossRef]

67. He, D.; Jiang, Y.; Lv, H.; Pan, M.; Mu, S. Nitrogen-doped reduced graphene oxide supports for noble metal catalysts with greatly enhanced activity and stability. Appl. Catal. B Environ. 2013, 132, 379-388. [CrossRef]

68. Li, X.-H.; Antonietti, M. Metal nanoparticles at mesoporous N-doped carbons and carbon nitrides: Functional mott-schottky heterojunctions for catalysis. Chem. Soc. Rev. 2013, 42, 6593-6604. [CrossRef] [PubMed]

69. Zhao, Z.-G.; Zhang, J.; Yuan, Y.; Lv, H.; Tian, Y.; Wu, D.; Li, Q.-W. In-situ formation of cobalt-phosphate oxygen-evolving complex-anchored reduced graphene oxide nanosheets for oxygen reduction reaction. Sci. Rep. 2013. [CrossRef] [PubMed]

70. Zhao, H.; Hui, K.S.; Hui, K.N. Synthesis of nitrogen-doped multilayer graphene from milk powder with melamine and their application to fuel cells. Carbon 2014, 76, 1-9. [CrossRef]

71. Li, Z.; Xu, Z.; Tan, X.; Wang, H.; Holt, C.M.B.; Stephenson, T.; Olsen, B.C.; Mitlin, D. Mesoporous nitrogen-rich carbons derived from protein for ultra-high capacity battery anodes and supercapacitors. Energy Environ. Sci. 2013, 6, 871-878. [CrossRef]

72. Senoz, E.; Stanzione, J.F.; Reno, K.H.; Wool, R.P.; Miller, M.E.N. Pyrolyzed chicken feather fibers for biobased composite reinforcement. J. Appl. Polym. Sci. 2013, 128, 983-989. [CrossRef]

73. Wang, X.; Zou, L.; Fu, H.; Xiong, Y.; Tao, Z.; Zheng, J.; Li, X. Noble metal-free oxygen reduction reaction catalysts derived from prussian blue nanocrystals dispersed in polyaniline. ACS Appl. Mater. Interfaces 2016, 8, 8436-8444. [CrossRef] [PubMed]

74. Wang, J.; Wang, G.; Miao, S.; Jiang, X.; Li, J.; Bao, X. Synthesis of Fe/Fe ${ }_{3} \mathrm{C}$ nanoparticles encapsulated in nitrogen-doped carbon with single-source molecular precursor for the oxygen reduction reaction. Carbon 2014, 75, 381-389. [CrossRef]

75. Wang, R.; Wang, H.; Zhou, T.; Key, J.; Ma, Y.; Zhang, Z.; Wang, Q.; Ji, S. The enhanced electrocatalytic activity of okara-derived N-doped mesoporous carbon for oxygen reduction reaction. J. Power Sources 2015, 274, 741-747. [CrossRef]

76. Zhou, R.; Qiao, S.Z. An Fe/N co-doped graphitic carbon bulb for high-performance oxygen reduction reaction. Chem. Commun. 2015, 51, 7516-7519. [CrossRef] [PubMed]

77. Strickland, K.; Miner, E.; Jia, Q.; Tylus, U.; Ramaswamy, N.; Liang, W.; Sougrati, M.-T.; Jaouen, F.; Mukerjee, S. Highly active oxygen reduction non-platinum group metal electrocatalyst without direct metal-nitrogen coordination. Nat. Commun 2015, 6, 7343. [CrossRef] [PubMed]

78. Rana, M.; Arora, G.; Gautam, U.K. N-and S-doped high surface area carbon derived from soya chunks as scalable and efficient electrocatalysts for oxygen reduction. Sci. Technol. Adv. Mater. 2016, 16, 014803. [CrossRef]

79. Chao, S.; Cui, Q.; Wang, K.; Bai, Z.; Yang, L.; Qiao, J. Template-free synthesis of hierarchical yolk-shell Co and $\mathrm{N}$ codoped porous carbon microspheres with enhanced performance for oxygen reduction reaction. J. Power Sources 2015, 288, 128-135. [CrossRef]

80. She, Y.; Lu, Z.; Ni, M.; Li, L.; Leung, M.K.H. Facile synthesis of nitrogen and sulfur codoped carbon from ionic liquid as metal-free catalyst for oxygen reduction reaction. ACS Appl. Mater. Interfaces 2015, 7, 7214-7221. [CrossRef] [PubMed]

81. Xi, J.; Xia, Y.; Xu, Y.; Xiao, J.; Wang, S. (Fe,Co)@nitrogen-doped graphitic carbon nanocubes derived from polydopamine-encapsulated metal-organic frameworks as a highly stable and selective non-precious oxygen reduction electrocatalyst. Chem. Commun. 2015, 51, 10479-10482. [CrossRef] [PubMed]

82. Wang, D.-W.; Su, D. Heterogeneous nanocarbon materials for oxygen reduction reaction. Energy Environ. Sci. 2014, 7, 576-591. [CrossRef]

83. Daems, N.; Sheng, X.; Vankelecom, I.F.; Pescarmona, P.P. Metal-free doped carbon materials as electrocatalysts for the oxygen reduction reaction. J. Mater. Chem. A 2014, 2, 4085-4110. [CrossRef]

84. Sheng, X.; Daems, N.; Geboes, B.; Kurttepeli, M.; Bals, S.; Breugelmans, T.; Hubin, A.; Vankelecom, I.F.; Pescarmona, P.P. N-doped ordered mesoporous carbons prepared by a two-step nanocasting strategy as highly active and selective electrocatalysts for the reduction of $\mathrm{O}_{2}$ to $\mathrm{H}_{2} \mathrm{O}_{2}$. Appl. Catal. B Environ. 2015, 176, 212-224. [CrossRef]

85. Wu, J.; Jin, C.; Yang, Z.; Tian, J.; Yang, R. Synthesis of phosphorus-doped carbon hollow spheres as efficient metal-free electrocatalysts for oxygen reduction. Carbon 2015, 82, 562-571. [CrossRef] 
86. Xiao, M.; Zhu, J.; Feng, L.; Liu, C.; Xing, W. Meso/macroporous nitrogen-doped carbon architectures with iron carbide encapsulated in graphitic layers as an efficient and robust catalyst for the oxygen reduction reaction in both acidic and alkaline solutions. Adv. Mater. 2015, 27, 2521-2527. [CrossRef] [PubMed]

87. Liu, X.; Wang, Y.; Dong, L.; Chen, X.; Xin, G.; Zhang, Y.; Zang, J. One-step synthesis of shell/core structural boron and nitrogen co-doped graphitic carbon/nanodiamond as efficient electrocatalyst for the oxygen reduction reaction in alkaline media. Electrochim. Acta 2016, 194, 161-167. [CrossRef]

88. Niu, W.; Li, L.; Liu, X.; Wang, N.; Liu, J.; Zhou, W.; Tang, Z.; Chen, S. Mesoporous N-doped carbons prepared with thermally removable nanoparticle templates: An efficient electrocatalyst for oxygen reduction reaction. J. Am. Chem. Soc. 2015, 137, 5555-5562. [CrossRef] [PubMed]

89. Kakaei, K.; Balavandi, A. Synthesis of halogen-doped reduced graphene oxide nanosheets as highly efficient metal-free electrocatalyst for oxygen reduction reaction. J. Colloid Interface Sci. 2016, 463, 46-54. [CrossRef] [PubMed]

90. Liu, Z.; Fu, X.; Li, M.; Wang, F.; Wang, Q.; Kang, G.; Peng, F. Novel silicon-doped, silicon and nitrogen-codoped carbon nanomaterials with high activity for the oxygen reduction reaction in alkaline medium. J. Mater. Chem. A 2015, 3, 3289-3293. [CrossRef]

91. Bag, S.; Mondal, B.; Das, A.K.; Raj, C.R. Nitrogen and sulfur dual-doped reduced graphene oxide: Synergistic effect of dopants towards oxygen reduction reaction. Electrochim. Acta 2015, 163, 16-23. [CrossRef]

92. Jiang, T.; Wang, Y.; Wang, K.; Liang, Y.; Wu, D.; Tsiakaras, P.; Song, S. A novel sulfur-nitrogen dual doped ordered mesoporous carbon electrocatalyst for efficient oxygen reduction reaction. Appl. Catal. B Environ. 2016, 189, 1-11. [CrossRef]

93. Li, W.; Yang, D.; Chen, H.; Gao, Y.; Li, H. Sulfur-doped carbon nanotubes as catalysts for the oxygen reduction reaction in alkaline medium. Electrochim. Acta 2015, 165, 191-197. [CrossRef]

94. Ju, Y.-W.; Yoo, S.; Kim, C.; Kim, S.; Jeon, I.-Y.; Shin, J.; Baek, J.-B.; Kim, G. Fe@N-graphene nanoplateletembedded carbon nanofibers as efficient electrocatalysts for oxygen reduction reaction. Adv. Sci. 2016, 3. [CrossRef] [PubMed]

95. Zhong, S.; Zhou, L.; Wu, L.; Tang, L.; He, Q.; Ahmed, J. Nitrogen-and boron-co-doped core-shell carbon nanoparticles as efficient metal-free catalysts for oxygen reduction reactions in microbial fuel cells. J. Power Sources 2014, 272, 344-350. [CrossRef]

96. Bai, J.; Zhu, Q.; Lv, Z.; Dong, H.; Yu, J.; Dong, L. Nitrogen-doped graphene as catalysts and catalyst supports for oxygen reduction in both acidic and alkaline solutions. Int. J. Hydrog. Energy 2013, 38, 1413-1418. [CrossRef]

97. Cheng, Y.; Tian, Y.; Fan, X.; Liu, J.; Yan, C. Boron doped multi-walled carbon nanotubes as catalysts for oxygen reduction reaction and oxygen evolution reactionin in alkaline media. Electrochim. Acta 2014, 143, 291-296. [CrossRef]

98. Pumera, M. Heteroatom modified graphenes: Electronic and electrochemical applications. J. Mater. Chem. C 2014, 2, 6454-6461. [CrossRef]

(C) 2016 by the authors; licensee MDPI, Basel, Switzerland. This article is an open access article distributed under the terms and conditions of the Creative Commons Attribution (CC-BY) license (http://creativecommons.org/licenses/by/4.0/). 